\title{
Asthma biomarkers in the age of biologics
}

\author{
Harold Kim ${ }^{1,2^{*}}$, Anne K. Ellis ${ }^{3,4}$, David Fischer ${ }^{1,5}$, Mary Noseworthy ${ }^{6}$, Ron Olivenstein ${ }^{7,8}$, Kenneth R. Chapman ${ }^{9,10}$ \\ and Jason Lee L1,12,13,14 $^{2}$
}

\begin{abstract}
The heterogeneous nature of asthma has been understood for decades, but the precise categorization of asthma has taken on new clinical importance in the era of specific biologic therapy. The simple categories of allergic and nonallergic asthma have given way to more precise phenotypes that hint at underlying biologic mechanisms of variable airflow limitation and airways inflammation. Understanding these mechanisms is of particular importance for the approximately $10 \%$ of patients with severe asthma. Biomarkers that aid in phenotyping allow physicians to "personalize" treatment with targeted biologic agents. Unfortunately, testing for these biomarkers is not routine in patients whose asthma is refractory to standard therapy. Scientific advances in the recognition of sensitive and specific biomarkers are steadily outpacing the clinical availability of reliable and non-invasive assessment methods designed for the prompt and specific diagnosis, classification, treatment, and monitoring of severe asthma patients. This article provides a practical overview of current biomarkers and testing methods for prompt, effective management of patients with severe asthma that is refractory to standard therapy.
\end{abstract}

Keywords: Asthma, Biomarkers, Phenotypes, Biologics

\section{Background}

Asthma remains a significant worldwide health condition in terms of both prevalence and severity within all regions and amongst every age group. There are an estimated 235-334 million asthma sufferers worldwide [1, 2], Asthma is responsible for approximately 250,000 deaths annually [3]. In Canada, physician-diagnosed asthma was reported by approximately 2.4 million Canadians aged $\geq 12$ years, corresponding to approximately $8.1 \%$ of the country's population [4]. Asthma rates are higher in children; the National Longitudinal Survey of Children and Youth (from 1994/1995 to 2008/2009) determined an asthma prevalence of $9.8 \%$ in Canadian children aged 2-7 years [5].

The heterogeneous nature of asthma has been well established with the recognition of multiple pathways, mediators, and systems involved in triggering the

\footnotetext{
*Correspondence: hlkimkw@gmail.com

1 Division of Clinical Immunology \& Allergy, Department of Medicine, Western University, 1151 Richmond St, London, ON N6A 5C1, Canada Full list of author information is available at the end of the article
}

characteristic airway inflammation and variable airflow limitation of asthma. Ongoing classification of different asthma phenotypes is a reflection of this heterogeneity. Indeed, severe asthma is often recognized as a specific asthma phenotype rather than an extreme manifestation of more commonplace asthma variants [6-8]. Severe asthma is defined by the joint European Respiratory Society/American Thoracic Society (ERS/ATS) guidelines according to the following criteria [9]:

- Requirement for treatment with high-dose inhaled corticosteroids (ICS) and a second controller (and/or systemic corticosteroids) to maintain control.

- Refractory to the treatment mentioned above.

- Incomplete management of comorbidities such as severe sinus disease or obesity.

The prevalence of severe, refractory asthma is generally estimated to be $5-10 \%$ of the total asthma population [914]. It is important to distinguish between asthma that is difficult to control and asthma that is truly severe. Initial assessment must rule out treatment confounders such as 
poor patient adherence and improper device technique as potential causes of suboptimal treatment response [9, 14-16]. The ERS/ATS guidelines cite reports indicating non-adherence as high as $32-56 \%$ [9]. Pooled data from 18 studies (January 1980 to October 2013) using electronic measurement of adherence to ICS among children with asthma determined a range of mean adherence rates of $28-71 \%$ (14 studies) and median adherence rates of $58-92 \%$ (4 studies) [17]. Although assessment of adherence can be challenging, physicians can encourage optimal self-management through open communication and shared decision making with the patient and family, education about the benefits of treatment and proper usage, and routine verification of medication usage and inhaler technique $[15,16]$. Treatment regimens should take into consideration preferences that are important to the patient and caregiver [15].

Biologic agents have been shown to be effective and safe in patients with moderate to severe asthma but with variable response amongst patients with different phenotypes [18-30]. The emergence of specific and sensitive biomarkers has equipped the treating physician with important tools to tailor therapy towards optimal outcomes.

The objectives of this article are to:

- Evaluate the role of biomarkers in the identification of specific patient phenotypes towards selection of the most appropriate biologic for an individual patient.

- Describe testing options for various biomarkers with respect to their reliability, noninvasiveness, and accessibility.

- Review biologic agents established as safe and effective in the management of asthma resistant to standard treatment.

\section{Asthma phenotypes}

From its origins in ancient Greek literature [31], the term "asthma" has evolved from a single disease entity, defined by a short list of clinical symptoms relating to the airway, to a broad term encompassing several distinct subgroups. The Merriam-Webster dictionary defines a phenotype as "the observable properties of an organism that are produced by the interactions of the genotype and the environment" [32].

The establishment of a definitive list of asthma phenotypes has been hindered by both the absence of a unified system of classification and by confounding comorbidities and co-existing conditions (Table 1) [33, 34]. Within this present uncertainty, several groups have attempted to identify and define the most prevalent phenotypes. The Asthma Phenotypes Task Force-a collaboration of the
Table 1 Comorbid conditions that complicate asthma phenotyping $[33,34]$

\begin{tabular}{|c|c|}
\hline Allergies & Churg-Strauss disease \\
\hline Rhinosinusitis & Pregnancy \\
\hline Gastroesophageal reflux disease & Chronic obstructive pulmonary \\
\hline Obstructive sleep apnea & disease \\
\hline $\begin{array}{l}\text { Smoking or exposure to second- } \\
\text { hand smoke }\end{array}$ & $\begin{array}{l}\text { Eczema } \\
\text { Infections and vaccination }\end{array}$ \\
\hline Obesity & Bronchiectasis and cystic fibrosis \\
\hline Hormonal influence & Exercise-induced bronchoconstric- \\
\hline Viruses and bacteria & tion \\
\hline Occupational exposure & Endocrine factors \\
\hline Vocal cord dysfunction & Conjunctivitis \\
\hline Food & Congestive heart failure \\
\hline Osteopenia and osteoporosis & Pulmonary embolism \\
\hline Psychological problems (e.g., anxi- & Medications \\
\hline ety \pm hyperventilation) & Primary ciliary dyskinesia \\
\hline
\end{tabular}

United States National Heart, Lung, and Blood Institute (NHLBI), the National Institute of Allergy and Infectious Diseases, the American Academy of Allergy, Asthma and Immunology, the ERS, and the ATS-proposed nine asthma phenotypes in three general categories (Table 2) [33]. Asthma phenotypes are generally separated according to allergy status, age of onset, and association with patient characteristics (e.g., exercise-induced, obesity related) [34-39].

Allergic asthma is widely identified as the most common phenotype $[15,33,34,40-43]$, particularly among children $[44,45]$. Approximately $60 \%$ of asthma is considered allergic [41, 42]. Atopy was described in the NHLBI and National Asthma Education and Prevention Program (NAEPP) 2007 Expert Panel Report 3 as the "strongest identifiable predisposing factor" for the development of asthma [15]. Furthermore, multi-allergen screening to define atopy was cited as the sole core biomarker recommendation by an expert working group organized by National Institutes of Health institutes and federal

Table 2 Asthma phenotypes task force recommendations: asthma phenotypes [33]

\begin{tabular}{ll}
\hline Category & Phenotype \\
\hline Trigger-induced asthma & (1) Allergic \\
& (2) Non-allergic \\
& (3) Aspirin-exacerbated respiratory \\
disease (AERD) & (4) Infection \\
& (5) Exercise-induced \\
Clinical presentation of asthma & (6) Pre-asthma wheezing in infants \\
& Episodic (viral) wheeze \\
& Multi-trigger wheezing \\
& (7) Exacerbation-prone asthma \\
& (8) Asthma associated with apparent \\
irreversible airflow limitation & (9) Eosinophilic and neutrophilic \\
Inflammatory markers of asthma & asthma \\
\hline
\end{tabular}


agencies [46]. Inflammation in allergic asthma is initiated by the activity of antigen-presenting cells that promote the production of type $2 \mathrm{~T}$ helper (Th2) cells from naïve $\mathrm{T}$ lymphocytes. Th2 cells then mediate the allergic asthma pathway through proinflammatory cytokines-i.e., interleukins (IL)-4, IL-5, IL-9, and IL-13-leading to the production of immunoglobulin $\mathrm{E}$ (IgE) early in the cascade and, later, eosinophils (Fig. 1) [47]. Allergic asthma is typically identified based on sensitization, as determined by at least one positive skin prick test to a perennial and/or clinically relevant allergen or in vitro testing for IgE.

Non-allergic asthma has been shown to have one or more different pathways leading to airway inflammation. Cytokines originating in the epithelium (IL-25, IL-33, and thymic stromal lymphopoietin) activate type 2 innate lymphoid cells, from which IL- 5 and IL-13 are produced and contribute to elevated eosinophil levels, mucus hypersecretion, and airway inflammation and hyperreactivity (Fig. 1) [47-49]. Non-allergic asthma tends to develop later in life and more predominantly in women than the allergic variety $[33,50,51]$. The prevalence of non-allergic asthma is generally considered to be $10-33 \%$ [51]. It appears to be associated with more severe asthma and a lower responsiveness to standard therapy [51]. Non-allergic asthma is diagnosed when allergic sensitization cannot be demonstrated using skin prick or in vitro IgE testing.

More precise identification of phenotypes may lead to the classification of asthma by endotypes. Endotypes are described as distinct asthma entities, as found in phenotype clusters, that are defined by a specific biological mechanism, providing a better understanding of the observable properties of that phenotype [34, 52].

\section{Biomarkers}

The identification and continued refinement of asthma phenotypes has given rise to a more personalized, targeted management approach, particularly in patients with severe refractory asthma [53]. Biological markers aid in our understanding and recognition of phenotypes, help to identify other treatments most likely to be effective for the individual asthma patient with an inadequate

\section{Trigger}

(allergens, pollutants, viruses, etc.)

Airway epithelium

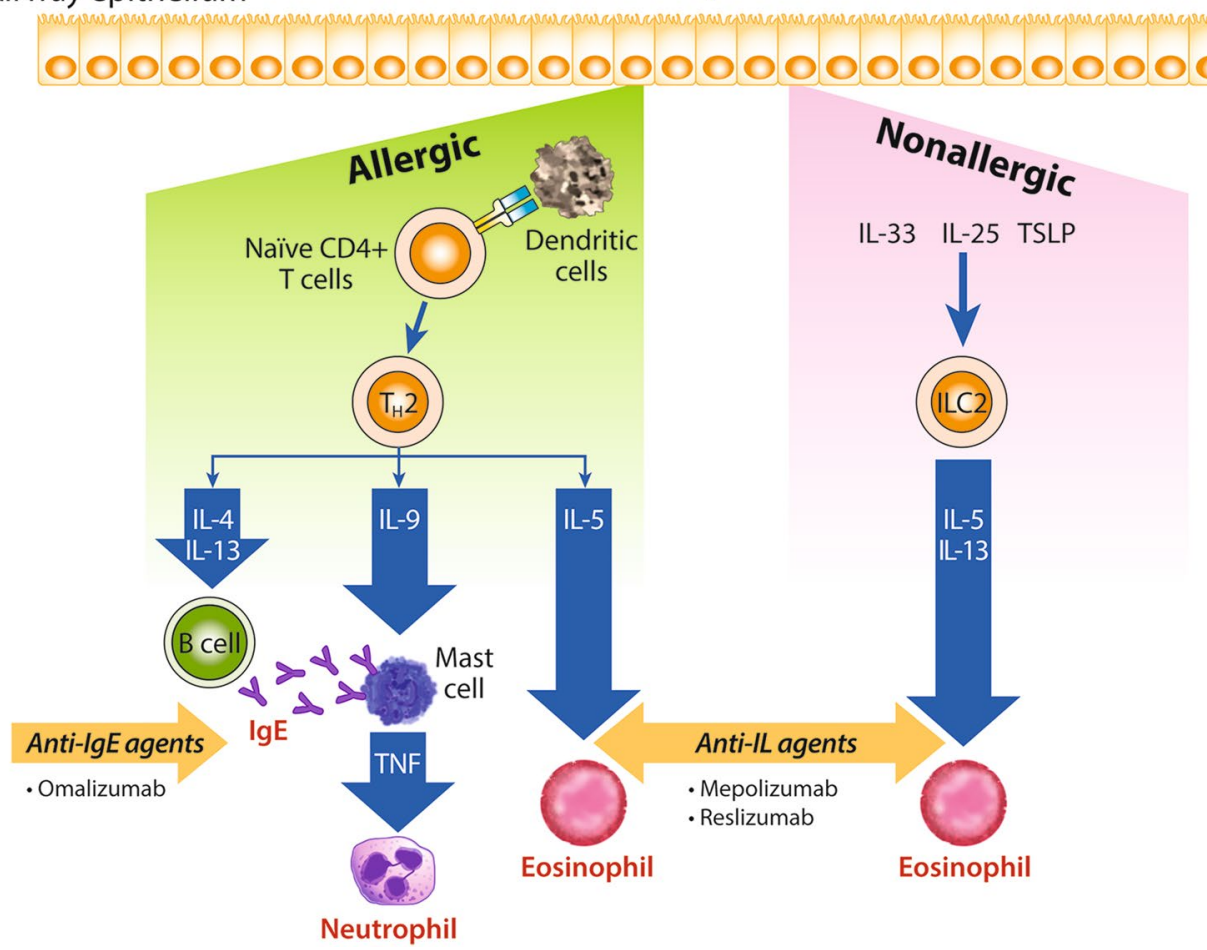

Fig. 1 Allergic and non-allergic inflammatory asthma cascade. IgE immunoglobulin E, IL interleukin, $T_{H} T$ helper, TNF tumour necrosis factor, TSLP thymic stromal lymphopoietin 
response to first-line pharmacotherapy, and have the potential to assess treatment response. The ongoing Assessing Biomarkers in a Real-world Severe Asthma (ARIETTA) study is evaluating the relationship between asthma biomarkers and disease-related health outcomes in approximately 1200 patients with severe asthma within more than 20 countries [54]. Other collaborations such as the Unbiased Biomarkers for the Prediction of Respiratory Disease Outcomes (U-BIOPRED) project [55, 56] and the Airways Disease Endotyping for Personalized Therapeutics (ADEPT) study group [57] have also contributed findings on the utility of asthma biomarkers. Currently targeted asthma biomarkers are listed in Table 3.

\section{$\lg \mathrm{E}$}

Allergen-specific IgE is the predominant biomarker for allergic asthma [58-60]. Its production is stimulated early in the allergic asthma cascade by the release of IL-4, IL-5, and IL-13 through activated Th2 cells. IgE binds to FceRI, which is expressed by several cells including mast cells, basophils, eosinophils, and B lymphocytes. The subsequent binding of allergens to allergen-specific IgE activates the release of proinflammatory mediators (e.g., tryptase, histamine, prostaglandins, leukotrienes), resulting in allergic symptoms [61-63]. Serum IgE levels have been shown to correlate closely with the presence and severity of asthma in adults, adolescents, and children $[44,58,64-69]$. It was also determined that serum IgE levels were associated with airway hyper-responsiveness, even in patients without a history of asthma symptoms or atopy [70].

\section{Eosinophils}

Produced in the bone marrow, eosinophils are recruited into areas of inflammation through complex interactions among cytokines and several other molecules [71]. Eosinophils depend particularly on IL-5 for their maturation, activation, and survival $[47,48]$. Eosinophils can be measured in both blood and sputum; the values differ significantly as a reflection of the local (sputum) versus systemic (blood) nature of these measurement methods (see the sections on blood and sputum testing). As with IgE, the presence of significant eosinophilia is associated with severe asthma; $[8,72-76]$ however, severe asthma is not identified exclusively with eosinophilia [6]. Kamath et al. argued against eosinophil being the most important effector cells in the pathogenesis of asthma based

Table 3 Currently used asthma biomarkers

\begin{tabular}{|c|c|c|c|c|c|}
\hline Biomarker & Testing method & Phenotype & Role in allergic pathway & Associated cytokines & Associated biologic agents \\
\hline $\lg E$ & Serum & Allergic (early onset) & $\begin{array}{l}\text { Binds to FcERI on mast cells, } \\
\text { basophils, and antigen- } \\
\text { presenting dendritic cells } \\
\text { Activates the release of } \\
\text { inflammatory mediators }\end{array}$ & $\mid \mathrm{L}-4, \mathrm{IL}-13$ & Omalizumab \\
\hline \multirow[t]{2}{*}{ Eosinophil } & \multirow[t]{2}{*}{ Blood, sputum } & \multirow[t]{2}{*}{$\begin{array}{l}\text { Eosinophilic (late onset)- } \\
\text { allergic and non-allergic }\end{array}$} & \multirow{2}{*}{$\begin{array}{l}\text { Modulates the immune } \\
\text { response } \\
\text { Promotes airway hyper- } \\
\text { responsiveness and } \\
\text { remodelling }\end{array}$} & IL-5 & $\begin{array}{l}\text { Mepolizumab, reslizumab, } \\
\text { benralizumab }\end{array}$ \\
\hline & & & & $\mid \mathrm{L}-4, \mathrm{IL}-13$ & Dupilumab \\
\hline Neutrophil & Sputum & Neutrophilic & $\begin{array}{l}\text { Significantly associated with } \\
\text { severe asthma } \\
\text { Accumulates in the airways } \\
\text { Prominent in airway secre- } \\
\text { tions during exacerbations }\end{array}$ & IL-8, IL-17 & \\
\hline \multicolumn{6}{|l|}{ Surrogate } \\
\hline Periostin & Serum, sputum & Eosinophilic & $\begin{array}{l}\text { Regulates eosinophil recruit- } \\
\text { ment and eosinophilic } \\
\text { tissue infiltration } \\
\text { Active in Th2 mucosal inflam- } \\
\text { mation, airway remodelling, } \\
\text { and expression of inflam- } \\
\text { matory mediators }\end{array}$ & $\mid \mathrm{L}-4, \mathrm{IL}-13$ & $\begin{array}{l}\text { Lebrikizumab, tralokinumab, } \\
\text { omalizumab }\end{array}$ \\
\hline DPP-4 & Serum & Eosinophilic, AERD & $\begin{array}{l}\text { Stimulates the proliferation of } \\
\text { bronchial smooth muscle } \\
\text { cells and human fetal lung } \\
\text { fibroblasts } \\
\text { Promotes fibronectin produc- } \\
\text { tion }\end{array}$ & IL-13 & Tralokinumab \\
\hline
\end{tabular}


on findings that demonstrated: (1) the presence of airway lumen eosinophilic inflammation is present in only $50 \%$ of patients; (2) intense eosinophilic inflammation alone does not induce asthma; and (3) a high frequency of exacerbations occurs even in the absence of airway eosinophilia [77]. Thus, the specific role of eosinophils in asthma severity remains a point of controversy [78].

\section{Neutrophils}

Neutrophils are the most abundant cell type found in induced sputum samples, independent of asthma status $[76,79]$. Markedly increased numbers of airway neutrophils were found in association with severe asthma and in patients experiencing acute severe exacerbations [76, 79-82]. Neutrophils are triggered by IL- 8 and produce enzymes and other factors that contribute to eosinophil activity [83]. Although it has been asserted that eosinophilic and neutrophilic asthma are not mutually exclusive conditions [77], neutrophilic inflammation has been shown to be associated with lower levels of forced expiratory volume in $1 \mathrm{~s}\left(\mathrm{FEV}_{1}\right)$, particularly post bronchodilator use, and methacholine responsiveness independent of eosinophilia [76, 80].

\section{Cytokines}

As indicated in the descriptions of the previously listed biomarkers, both the allergic and non-allergic pathways of asthma inflammation are mediated at multiple points by the various ILs. IL-4, IL-5, and IL-13 originate from Th2 lymphocytes and mast cells, and are involved in the mediation of Th2 inflammation [13, 84-88]. IL-5 selectively acts on eosinophils and basophils; it promotes eosinophil recruitment, differentiation, maturation, and activation $[84,89,90]$, as well as the maturation, growth, activation, and survival of basophils [91]. IL-4 and IL-13 are active in IgE synthesis, and mediate eosinophil recruitment and activation, mucus secretion, and airway remodelling $[84,92,93]$. IL-13 is also involved in the activation and proliferation of bronchial fibroblasts that increase in bronchial hyper-responsiveness [94, 95].

IL-9 and IL-11 have been shown to be more specifically involved in the severe asthma cascade $[13,96]$. IL-9 is derived from Th2 cells, but can also be produced by a host of other cells under specific conditions [97]. It is a significant contributor to the differentiation and proliferation of mast cells $[98,99]$. IL- 11 has been shown to be involved in chronic airway remodelling [96]. IL-17 is another cytokine that has been correlated with severe asthma [100-102]. Researchers have found an association between IL-17 and increased neutrophilic airway inflammation [103], as well as with the induction of IL-6 and the production of IL-8 from fibroblasts [104].
Cytokines such as IL-25 and IL-33 are active in the early stages of the inflammatory cascades of both allergic and non-allergic asthma. IL-25 and IL-33 are involved in the stimulation of type 2 innate lymphoid cells (ILC2s), which are another source of IL-5, IL-13, and (to a lesser extent) IL-4 [47, 105-107]. A number of genome-wide association studies have identified IL-33 and its receptor genes as highly implicated in the development of asthma [108].

IL-22 appears to exhibit both pro- and anti-inflammatory activity. It is found in high concentration in patients with severe asthma [109], and blockage of IL-22 significantly reduces eosinophilic inflammation, eosinophil recruitment, mucus production, and Th2 cytokine production in an asthmatic mouse model [110]. In the same study, however, IL-22 inhibition resulted in increased Th2 2 cytokine production and greater allergic lung inflammation. This effect may be secondary to the inhibition of IL-22, with the increased production of IL-25 in lung epithelial cells [111].

IL-23 is involved in the differentiation of Th17 cells and in the production of IL-17 and IL-22 [112-115]. It is also a key regulator of IL-17 [116].

\section{Periostin}

The extracellular matrix protein, periostin, has been found to be a downstream molecule of IL-4 and IL-13, which upregulate periostin expression in bronchial epithelial cells and fibroblasts [117-119]. IL-13-stimulated epithelial cells secrete periostin into the extracellular matrix. It plays a role in the regulation of eosinophil recruitment and tissue infiltration, accumulation in Th2 mucosal inflammation, and is also involved in airway remodelling and increased expression of inflammatory mediators [120, 121]. Periostin has been proposed as a surrogate biomarker for type 2 immunity to predict the efficacy of treatments targeting IL-13 and IgE [122].

\section{Dipeptidyl peptidase 4 (DPP-4)}

Little research has been published on the activity of DPP-4 in human asthma. Rat models have shown increased enzyme activity further to allergen challenge [123], and topical (but not oral) DPP-4 inhibition in rats reduced airway hyper-responsiveness [124]. In human subjects, IL-13 was identified as a significant inducer of DPP-4 [125]. DPP-4 has been found to be a stimulator of proliferation of bronchial smooth muscle cells and human fetal lung fibroblasts, and it promotes the production of fibronectin [126]. There is evidence that DPP-4 may serve as a biomarker for aspirin-exacerbated respiratory disease [127]. 


\section{Currently available tests: practical points for optimal use}

The identification of biomarkers has been shown to provide valuable information and guidance for selecting therapies that can result in best patient outcomes. However, in order for this information to become actionable, the testing method must be sufficiently sensitive and specific. The practicality of a biomarker test is inversely proportional to its invasiveness. Also, availability and cost to the healthcare system and/or the patient are also necessary to consider for the selection of the most appropriate test.

The current diagnosis of asthma through a combination of clinical history with pulmonary function testing and methacholine or exercise challenge test [128] does not specifically characterize or quantify airway inflammation. Bronchoscopy/biopsy and bronchoalveolar lavage continue to be useful for the assessment of the asthma patient and for detection of asthma biomarkers, and are safe even in severe asthma when proper precautions are used [129-135]. However, the invasive nature of these procedures limits their usefulness, particularly for the purpose of ongoing monitoring.

As a standard approach, all patients with moderate to severe or difficult-to-treat asthma should undergo the following tests:

- Aeroallergen skin prick testing.

- Total IgE.

- Complete blood count (CBC) with differential, including blood eosinophil level.

These tests are reliable and are easily accessed in the Canadian healthcare system. Additional tests may be considered, depending on the specific patient profile. Details of available tests are presented below.

\section{Allergy skin testing}

Skin prick testing is a widely available, inexpensive, simple, and minimally invasive method to assess the patient's allergic status to an IgE-mediated allergen [16, 136]. Another advantage is that results are generally known within 15-20 min of application of the reagents to the skin. Skin prick testing can also be used to test for atopic response to less common allergens for which no specific IgE antibody test is available, such as some medications [136]. The test has been found to be sensitive when performed by an experienced tester with standardized extracts, and reproducible $[16,136,137]$. In this population, technique is as important as testing device to maximize accuracy of outcome [138]. The need for a consensus on minimal tester standards has been highlighted to minimize the gap between expert recommendation and daily practice [139].

\section{Blood IgE testing}

Testing of a patient's blood remains an important component in the diagnosis of asthma; the detection of elevated IgE levels and eosinophils can be used to assist in identifying allergic sensitivity. Specific IgE (i.e., IgE directed against a specific allergen) and eosinophil count were confirmed as the most consistent biomarkers to measure the risk of asthma in children [140]. Agreement between in vitro specific IgE and skin prick testing was $85-90 \%$, depending on the allergen and testing method [136]. In a comparison between the two methods to detect airway reactivity to house dust mite, skin prick testing was more sensitive but IgE testing was more specific [141]. Measurement of specific and total (i.e., sum of all specific IgE levels) serum IgE levels can be useful in the diagnosis of asthma and to distinguish between allergic and non-allergic asthma [61, 62, 68, 142-144]. Measurement of total IgE is also essential to determine suitable candidates for treatment with omalizumab (i.e., those with serum total IgE levels in the range of $30-700 \mathrm{IU} / \mathrm{mL}$ ), as well as to establish proper dosing. Specific IgE does not improve reliability over skin prick testing and is more expensive; however, it can be advantageous to use in uncooperative patients, those who have extensive skin conditions, or if their allergy history indicated a risk of anaphylaxis [135]. If specific IgE is being ordered for consideration of selecting an appropriate biologic agent, screening for perennial allergens such as dust mite would have the best rationale. The mean total serum IgE concentration for healthy adults was identified in 1969 as $250 \mathrm{ng} / \mathrm{mL}$, compared with a mean level of up to $2800 \mathrm{ng} / \mathrm{mL}$ in atopic individuals and $1600 \mathrm{ng} / \mathrm{mL}$ for those with extrinsic asthma [145]. Normal total serum IgE is now understood to be agedependent $[145,146]$. The reference intervals range from 2 to $34 \mathrm{IU} / \mathrm{mL}$ in infants aged 6-12 months to 2-696 IU/ $\mathrm{mL}$ in children aged 9-12 years, and then decreases to $2-214 \mathrm{IU} / \mathrm{mL}$ for adults aged $\geq 18$ years (Table 4) [147]. Interestingly, total and specific serum IgE were found to decrease with age in patients with asthma [148].

\section{Other blood tests}

Blood eosinophil count is an accurate diagnostic indicator of mild, moderate, and severe eosinophilic asthma [149-153]. Blood eosinophil count and the level of serum eosinophil protein were shown to be indicators of the short-term increases in asthma symptoms (wheezing, cough, dyspnea, and exercise-induced asthma) and bronchial hyper-responsiveness, reduction in $\mathrm{FEV}_{1}$, and the need for corticosteroid treatment in patients with mild to 
Table 4 Total serum IgE reference intervals. Reproduced from [147]

\begin{tabular}{ll}
\hline Age & Reference interval $(\mathrm{IU} / \mathrm{mL})$ \\
\hline $6-12$ months & $2-34$ \\
$1-2$ years & $2-97$ \\
3 years & $2-199$ \\
$4-6$ years & $2-307$ \\
$7-8$ years & $2-403$ \\
$9-12$ years & $2-696$ \\
$13-15$ years & $2-629$ \\
$16-17$ years & $2-537$ \\
$\geq 18$ years & $2-214$ \\
\hline
\end{tabular}

moderate asthma [154]. Clinical trials involving mepolizumab found that the rate of clinically significant asthma exacerbations varied according to blood eosinophil level, as opposed to sputum $[26,150,151]$. The normal range of blood eosinophil count is $30-350$ cells/ $\mu \mathrm{L}$; [155] however, there is controversy with respect to the cut off level associated with increased risk of asthma complications. Mepolizumab trials employed blood eosinophil cut offs of $\geq 150$ to $\geq 300$ cells $/ \mu \mathrm{L}[24-26,151,156]$. This is in line with the findings of the Epidemiological study on the Genetics and Environment of Asthma group, who concluded that a blood eosinophil level $\geq 250$ cells $/ \mu \mathrm{L}$ correlated with more active asthma (i.e., lower $\mathrm{FEV}_{1}$ ) [157]. However, several studies determined that poor asthma control was associated with a higher eosinophil cut off. A large-scale $(\mathrm{N}=130,248)$ UK cohort study used negative binomial regression to identify that poorer asthma control and more severe exacerbations were experienced by patients with blood eosinophil counts $>400$ cells $/ \mu \mathrm{L}$ [158]. Zieger et al. likewise concluded that a blood eosinophil count $>400$ cells $/ \mu \mathrm{L}$ was an independent risk factor for asthma exacerbations and asthma-related emergency department visits or hospitalizations [153].

\section{Other useful evaluations Serum periostin}

Elevated serum levels of periostin have been associated with asthma activity and severity, and with the presence of late-onset eosinophilic asthma [159, 160]. Organizers of the Bronchoscopic Exploratory Research Study of Biomarkers in Corticosteroid-refractory Asthma (BOBCAT) concluded that serum periostin is potentially useful for the selection of agents that target Th2 inflammation [161]. In their study, eosinophil-high and eosinophil-low subjects were differentiated by periostin with a positive predictive value of $93 \%$, and serum periostin levels were more consistent than blood eosinophil counts. This group also determined that serum periostin was a significantly better predictor of airway eosinophilia than other biomarkers tested, including IgE, peripheral blood eosinophils, fractional exhaled nitric oxide (FeNO), and YKL-40 [161]. Wagener et al. concluded, however, that periostin did not distinguish between eosinophilic and non-eosinophilic airway inflammation [149]. A precise definition of high periostin levels has not been established; most studies involving lebrikizumab employed the median periostin level across the study cohort as the cut off between high- and low-periostin groups [162-164]. The requirement of an enzyme-linked immunosorbent assay limits the availability of this test, and periostin levels are rarely obtained outside of clinical research.

\section{Induced sputum}

Induction of a sputum sample is an effective and noninvasive method of biomarker collection in asthma patients as young as 6 years of age [128, 165, 166]. This test produces a differential count of 400 inflammatory cell types, including eosinophils, neutrophils, macrophages, lymphocytes, and epithelial cells. Reproducibility, validity, and responsiveness have been demonstrated [167, 168]. In a population of healthy adults in Western Canada, Davidson et al. determined the following mean ( \pm standard deviation) differential cell percentages: neutrophils $50.3 \pm 23.5 \%$; eosinophils $1.4 \pm 2.3 \%$; macrophages $43 \pm 22.8 \%$; lymphocytes $2.6 \pm 5.2 \%$; and bronchial epithelial cells $2.2 \pm 4.8 \%$ [169]. Induced sputum has also been instrumental in identifying four inflammatory phenotypes: eosinophilic, neutrophilic, paucigranulocytic (i.e., normal neutrophil and eosinophil levels), and mixed granulocytic (i.e., elevated levels of both neutrophils and eosinophils) [166]. The disadvantages of induced sputum counts in Canada include high cost, technical demand, required time, and limited availability to only a few sites across Canada.

The Canadian Thoracic Society's (CTS) 2012 asthma guidelines identified a mean differential sputum eosinophil count of $<2-3 \%$ as normal [128]. An elevated eosinophil count is associated with symptomatic asthma. During a response to airborne allergen exposure [167], ICs were shown to reduce eosinophil count [167, 170, 171], and a systematic review by Petsky et al. found that asthma treatment adjusted to sputum eosinophil count was associated with a significant reduction in the number of exacerbations [172]. The CTS guidelines suggest that sputum eosinophil counts be measured in adult asthma patients for the adjustment of anti-inflammatory treatment [128], and conducted in conjunction with standard asthma control assessment.

Sputum periostin is associated with persistent airflow limitation, as well as ICS resistance in eosinophilic asthma [173]. It is also a potential marker for airway remodelling [174]. Simpson et al. determined that 
periostin levels are significantly lower in sputum than in serum, and while both sputum and serum periostin levels are significantly related to sputum eosinophil levels, neither exhibits a high level of prediction of the presence of eosinophilic asthma [175].

\section{FeNO}

The generation of nitric oxide in the airways is indicative of Th2 inflammation [176, 177]. Study results conflict regarding the ability of FeNO to classify asthma severity [178-181]. In a six-year longitudinal study of patients with difficult-to-treat asthma, van Veen et al. determined that FeNO can predict accelerated decline of lung function [182]. FeNO assessed airway inflammation as accurately as induced sputum analysis [183], and predicted asthma relapse in asymptomatic children in the month after ICS discontinuation [184].

The CTS guidelines have not recommended routine use of FeNO for the adjustment of ICS dose, citing insufficient evidence [128]. This conclusion is in line with guidelines published by the ERS/ATS, the NHLBI/ NAEPP, and the British Thoracic Society/Scottish Intercollegiate Guidelines Network [9, 15, 185]. However, FeNO is supported by the ATS for the detection of eosinophilic airway inflammation, assessing the potential need for and probability of response to ICS, and evaluating ICS adherence [186]. FeNO is simple to perform, usable in infants and preschool children, and results are immediately available; however, its relative sensitivity and specificity for eosinophilic inflammation are uncertain and accurate FeNO measurement is confounded by atopic status, smoking, and ICS use. It is available in most asthma clinics and some specialist clinics.

\section{Biomarker-guided management options Available biologics}

The advent of biologic agents has revolutionized the management of patients with severe refractory asthma. These agents target different components of the inflammatory cascade, and are indicated for specific patient phenotypes (Table 5). Their current or anticipated availability suggests a provisional role for the use of biomarkers in the selection of biologics for severe asthma therapy.

\section{Omalizumab (anti-IgE)}

Omalizumab was approved in 2005 by Health Canada, and is indicated for the management of adult and pediatric (aged $\geq 6$ years) patients with moderate to severe persistent asthma that is uncontrolled by ICS, and who exhibit allergic reactivity to a clinically relevant aeroallergen [187]. Initial trials demonstrating the safety and effectiveness of omalizumab in the management of moderate to severe allergic asthma [18-23] are supported by long-term ( $\geq 52$ weeks) and real-world studies [188-191] and more than 400,000 patient-years of experience [192]. It is recommended as Step 5 add-on treatment in the 2016 Global Initiative for Asthma (GINA) guidelines for patients with moderate to severe allergic asthma [16]. Omalizumab binds IgE with high affinity and competitively inhibits its interaction with FceRI, leading to the reduced expression of FceRI on mast cells, basophils, and dendritic cells $[60,187]$. The presence of omalizumab:IgE complexes increases serum total IgE levels after the agent has been initiated and these levels may remain elevated for up to 1 year after omalizumab has been discontinued. Thus, caution is indicated against basing reassessment of the dosing regimen on serum total IgE levels taken during this time period [187]. Although IgE is the principal biomarker when considering the administration of omalizumab in treatmentrefractory asthma patients, other biomarkers may be valuable in guiding omalizumab use. Investigators of the EXTRA study noted that reductions in exacerbations associated with omalizumab use versus placebo were substantially greater in high- versus low-biomarker subgroups for all biomarkers studied: eosinophils, periostin, and FeNO [176]. Serum IgE and periostin levels were determined to be useful markers of response to omalizumab [193].

\section{Mepolizumab (IL-5 inhibitor)}

Mepolizumab was approved by Health Canada in 2015 for the add-on maintenance treatment of adult patients aged $\geq 18$ years with severe eosinophilic asthma that is uncontrolled with ICS and an additional asthma agent [194]. Eosinophilic asthma was defined in mepolizumab trials as a blood eosinophil count of $\geq 150$ cells $/ \mu \mathrm{L}$ at initiation of mepolizumab or $\geq 300$ cells/ $\mu \mathrm{L}$ in the previous 12 months. Mepolizumab binds to IL-5 with high affinity, disrupting the production and survival of eosinophils. The agent was proven safe and effective in three randomized, double-blind clinical trials [24-26], and benefit beyond 48 months was also determined [195, 196]. The 2016 GINA guidelines added mepolizumab to its recommended Step 5 treatment options for patients aged $\geq 12$ years with severe eosinophilic asthma [16]. Blood eosinophil count was found to be a more reliable marker of mepolizumab activity than sputum eosinophil measurement $[26,151]$. Early studies that failed to demonstrate clinical improvement (airway hyperreactivity, peak expiratory flow, and $\mathrm{FEV}_{1}$ ) despite marked reductions in blood and sputum eosinophil count underline the importance of biomarker use for identification of appropriate candidates. 
Table 5 Approved and investigational biologic agents

\begin{tabular}{|c|c|c|c|c|c|}
\hline Approved agent & \multicolumn{2}{|l|}{ Indication } & $\begin{array}{l}\text { Therapeutic } \\
\text { target }\end{array}$ & Biomarkers & Dosing \\
\hline Omalizumab (Xolair $\left.{ }^{\circledR}\right)$ & \multicolumn{2}{|c|}{$\begin{array}{l}\text { Moderate to severe persistent allergic asthma } \\
\text { Positive skin test or in vitro reactivity to a perennial } \\
\text { aeroallergen } \\
\text { Patient is inadequately controlled with ICS } \\
\geq 6 \text { years of age; add-on therapy for } 6-11 \text { years of age } \\
\text { Chronic idiopathic urticaria } \\
\text { Symptomatic despite } \mathrm{H} 1 \text { antihistamine treatment } \\
\geq 12 \text { years of age } \\
\text { US } \\
\text { As Canadian PM, except that eligible patient age } \\
\text { is } \geq 6 \text { years } \\
\text { EU } \\
\text { Add-on therapy to improve control of severe persistent } \\
\text { allergic (convincing lgE-mediated) asthma in patients } \\
\text { aged } \geq 6 \text { years } \\
\text { Positive skin test or in vitro reactivity to a perennial aer- } \\
\text { oallergen + frequent daytime symptoms or night-time } \\
\text { awakenings } \\
\geq 12 \text { years: reduced lung function (FEV }<80 \% \text { ) } \\
\text { Multiple documented exacerbations despite daily high- } \\
\text { dose ICS + long-acting inhaled beta }{ }_{2} \text {-agonist }\end{array}$} & $\lg E$ & $\begin{array}{l}\text { IgE (serum) } \\
\text { Periostin (serum, } \\
\text { sputum) }\end{array}$ & $\begin{array}{l}75-375 \text { mg SC every } \\
\text { 2-4 weeks } \\
\text { Dose determined by } \\
\text { serum total lgE level } \\
\text { and body weight }\end{array}$ \\
\hline $\begin{array}{l}\text { Mepolizumab } \\
\left(\text { Nucala }^{\circledR}\right)\end{array}$ & \multicolumn{2}{|c|}{$\begin{array}{l}\text { Severe eosinophilic asthma } \\
\text { Add-on maintenance treatment } \\
\geq 12 \text { years of age } \\
\text { Patient is inadequately controlled with high-dose ICS } \\
\text { and } \geq 1 \text { additional asthma controller } \\
\text { Blood eosinophil count } \geq 150 \text { cells/ } \mu \mathrm{L} \text { at initiation of } \\
\text { treatment or } \geq 300 \text { cells/ } \mu \mathrm{L} \text { in the past } 12 \text { months } \\
\text { US } \\
\text { As Canadian PM } \\
\text { No details provided on lack of control on other asthma } \\
\text { medication or specific blood eosinophil level } \\
\text { EU } \\
\text { As Canadian PM } \\
\text { Specifies refractory nature of severe eosinophilic asthma } \\
\text { Adult patients } \\
\text { No details provided on specific blood eosinophil level }\end{array}$} & $\| L-5$ & $\begin{array}{l}\text { Eosinophil (blood, } \\
\text { sputum) }\end{array}$ & $\begin{array}{l}100 \text { mg SC every } \\
4 \text { weeks }\end{array}$ \\
\hline $\begin{array}{l}\text { Reslizumab (Cin- } \\
\text { qair }^{\mathrm{TM}} \text { ) }\end{array}$ & \multicolumn{2}{|c|}{$\begin{array}{l}\text { Severe eosinophilic asthma } \\
\text { Add-on maintenance treatment } \\
\geq 18 \text { years of age } \\
\text { Patient is inadequately controlled with medium- to high- } \\
\text { dose ICS and } \geq 1 \text { additional asthma controller } \\
\text { Blood eosinophil count } \geq 400 \text { cells/ } \mu \text { L at initiation of } \\
\text { treatment } \\
\text { US } \\
\text { As Canadian PM } \\
\text { No details provided on lack of control on other asthma } \\
\text { medication or specific blood eosinophil level } \\
\text { EU } \\
\text { As Canadian PM } \\
\text { No details provided on specific blood eosinophil level } \\
\text { Specifies high-dose ICS }\end{array}$} & $\| L-5$ & $\begin{array}{l}\text { Eosinophil (blood, } \\
\text { sputum) }\end{array}$ & $\begin{array}{l}3 \mathrm{mg} / \mathrm{kg} \mathrm{IV} \mathrm{(20-} \\
50 \text { min) every } \\
4 \text { weeks }\end{array}$ \\
\hline Investigational agent & \multicolumn{3}{|c|}{ Study population(s) } & Study dosing & Study results \\
\hline Benralizumab & IL-5Ra & $\begin{array}{l}\text { Patients } \\
\text { eosinor } \\
\text { (blood } \\
\text { count } \\
\geq 12 \text { yea } \\
\text { Uncontr } \\
\text { exacerk } \\
\text { despite } \\
\text { and LA }\end{array}$ & $\begin{array}{l}\text { with severe } \\
\text { philic asthma } \\
\text { eosinophil } \\
\geq 300 \text { cells/ } \mu \mathrm{L} \text { ) } \\
\text { ars of age } \\
\text { olled ( } \geq 2 \\
\text { bations) } \\
\text { e high-dose ICS } \\
\text { BA use }\end{array}$ & $\begin{array}{l}30 \text { mg SC every } 4 \text { or } \\
8 \text { weeks }\end{array}$ & $\begin{array}{l}\text { Significant reduction of } \\
\text { annual asthma exacer- } \\
\text { bation rate } \\
\text { Significantly improved } \\
\text { prebronchodilator } \mathrm{FEV}_{1}\end{array}$ \\
\hline
\end{tabular}


Table 5 continued

\begin{tabular}{|c|c|c|c|c|c|}
\hline Investigational agent & Therapeutic target & Biomarkers & Study population(s) & Study dosing & Study results \\
\hline Dupilumab & IL-4/IL-13 & $\begin{array}{l}\text { Eosinophil (blood, } \\
\text { sputum) }\end{array}$ & $\begin{array}{l}\text { Patients with uncon- } \\
\text { trolled persistent } \\
\text { asthma } \\
\geq 18 \text { years of age } \\
\text { Taking medium- to } \\
\text { high-dose ICS and a } \\
\text { LABA }\end{array}$ & $\begin{array}{l}200 \text { or } 300 \text { mg SC every } \\
2 \text { weeks or every } \\
4 \text { weeks }\end{array}$ & $\begin{array}{l}\text { Significant increases in } \\
\mathrm{FEV}_{1} \\
\text { Reduction in severe } \\
\text { exacerbations }\end{array}$ \\
\hline Lebrikizumab & $\operatorname{IL}-13$ & $\begin{array}{l}\text { Periostin } \\
\text { Eosinophil (blood) }\end{array}$ & $\begin{array}{l}\text { Patients with uncon- } \\
\text { trolled asthma } \\
\geq 18 \text { years of age } \\
\text { Pre-bronchodilator } \\
\mathrm{FEV}_{1} 40-80 \% \text { pre- } \\
\text { dicted } \\
\text { Periostin } \geq 50 \mathrm{ng} / \mathrm{mL} \\
\text { or blood eosino- } \\
\text { phils } \geq 300 \text { cells/ } / \mathrm{L} \\
\text { ICS and } \geq 1 \text { controller } \\
\text { medication }\end{array}$ & $\begin{array}{c}37.5 \text { or } 125 \text { mg SC } \\
\text { every } 4 \text { weeks }\end{array}$ & $\begin{array}{l}\text { No consistent significant } \\
\text { reduction in exacerba- } \\
\text { tions }\end{array}$ \\
\hline Tralokinumab & $\mathrm{IL}-13$ & $\begin{array}{l}\text { Periostin } \\
\text { DPP-4 }\end{array}$ & $\begin{array}{l}\text { Patients with severe } \\
\text { uncontrolled asthma } \\
\geq 18 \text { years of age } \\
\text { Taking high-dose ICS } \\
\text { and a LABA }\end{array}$ & $\begin{array}{l}300 \text { mg SC every } 2 \text { or } \\
4 \text { weeks }\end{array}$ & $\begin{array}{l}\text { No significant reduction } \\
\text { in exacerbation rate } \\
\text { Dosing every } 2 \text { weeks } \\
\text { significantly improved } \\
\text { prebronchodilator FEV }\end{array}$ \\
\hline
\end{tabular}

FEV ${ }_{1}$ forced expiratory volume in $1 \mathrm{~s}, L A B A$ long-acting beta2 agonist

\section{Reslizumab (IL-5 inhibitor)}

Reslizumab was approved by Health Canada in 2016. Like mepolizumab, reslizumab is indicated for add-on maintenance treatment of patients aged $\geq 18$ years with severe eosinophilic asthma-defined in reslizumab trials as a blood eosinophil count $\geq 400$ cells $/ \mu \mathrm{L}$ - and who are inadequately controlled with ICS and an additional asthma medication [197]. Reslizumab received its approval based on two randomized, double-blind trials [29]. Although blood eosinophil count is the approved measure for determination of eligibility to take reslizumab, this agent has also shown the ability to reduce sputum eosinophil levels [28].

\section{Investigational biologics}

Several biologics are currently being tested in Phase III trials to confirm their safety and efficacy in asthma patients.

Benralizumab binds to the $\alpha$ subunit of the IL- 5 receptor and reduces the number of IL-5R $\alpha$-producing cells through its antibody-directed, cell-mediated cytotoxic effect on eosinophils and basophils [198]. In two Phase III trials, benralizumab significantly reduced asthma exacerbations and improved pre-bronchodilator $\mathrm{FEV}_{1}$ $[199,200]$. Patient stratification in these two trials was by baseline blood eosinophil count $(\geq 300$ cells/ $\mu \mathrm{L}$ versus $<300$ cells $/ \mu \mathrm{L})$.

Dupilumab acts on the $\alpha$ subunit of the IL- 4 receptor and blocks signal transduction of both IL-4 and IL-13 [201]. It produced a greater reduction of exacerbations in patients with persistent moderate-to-severe asthma and eosinophilia compared with placebo [202]. Eligible patients had elevated eosinophil counts according to blood or sputum screening; in this study by Wenzel et al., the specific cut-off levels were $\geq 300$ cells $/ \mu \mathrm{L}$ for blood and $\geq 3 \%$ for sputum eosinophil. In a Phase IIb trial, dupilumab was associated with improvements in lung function and severe exacerbations in patients with uncontrolled persistent asthma regardless of baseline eosinophil count [203].

IL-13 inhibition is the target of two other experimental agents, lebrikizumab and tralokinumab [204, 205]. In parallel Phase III trials, lebrikizumab appeared to reduce IL-13, but asthma exacerbations were not significantly reduced [206]. Further lebrikizumab trials have been suspended. Tralokinumab failed to meet its primary endpoint of a significant reduction in the rate of asthma exacerbations over 52 weeks in the Phase III STRATOS 1 trial [207]. The ongoing STRATOS 2 trial is analyzing this same primary outcome in a subset of patients identified with periostin and DPP-4 measurement as having high IL-13 activity.

\section{Conclusion}

It has been established that asthma is a heterogeneous condition, comprising a phenotypic spectrum of patient populations. Under this broad term, severe asthma itself covers a series of subgroups with specific characteristics, symptom profiles, and biochemical mechanisms of disease. Biologic agents represent a significant opportunity 
to administer individualized treatment for patients who do not respond to traditional asthma therapy. In this review, we have shown the importance of biomarkers to identify which patient phenotypes can be expected to derive the greatest benefit from these agents, and, for some, as indicators of treatment response. All patients with asthma in whom initiation of biologic therapy is being considered should undergo aeroallergen skin prick testing and IgE measurement to assess for the allergic asthma phenotype, and a CBC with differential to assess for elevated eosinophil levels. These biomarkers are both readily accessible and useful to provide accurate clinical information about the underlying asthma phenotype. The optimization of biomarker testing methods by combining greatest sensitivity and specificity with non-invasiveness, availability, and affordability is critical to the continued advancement of asthma control.

\section{Authors' contributions}

All authors reviewed the manuscript. All authors read and approved the final manuscript.

\begin{abstract}
Author details
${ }^{1}$ Division of Clinical Immunology \& Allergy, Department of Medicine, Western University, 1151 Richmond St, London, ON N6A 5C1, Canada. ${ }^{2}$ Division of Clinical Immunology \& Allergy, Department of Medicine, McMaster University, 1280 Main Street West, Hamilton, ON L8S 4K1, Canada. ${ }^{3}$ Division of Allergy \& Immunology, Department of Medicine, Queen's University, 15 Arch Street, Kingston, ON K7L 3N6, Canada. ${ }^{4}$ Department of Biomedical and Molecular Sciences, School of Medicine, Queen's University, Kingston, ON, Canada. ${ }^{5}$ Canadian Society of Allergy and Clinical Immunology, P.O. Box 51045, Orleans, ON K1E 3W4, Canada. ${ }^{6}$ Alberta Children's Hospital, University of Calgary, 2500 University Dr. NW, Calgary, AB T2N 1N4, Canada. ${ }^{7}$ Division of Respiratory Medicine, Faculty of Medicine, McGill University, 3605 Rue De la Montagne, Montreal, QC H3G 2M1, Canada. ${ }^{8}$ Acute Care Division, Montreal Chest Institute, 1001 Décarie Blvd, Montreal, QC H4A 3J1, Canada. ${ }^{9}$ Asthma and Airway Centre, Toronto Western Hospital, University Health Network, 399 Bathurst Street, Toronto, ON M5T 2S8, Canada. ${ }^{10}$ Division of Respirology, Department of Medicine, University of Toronto, 1 King's College Circle, \#3172, Toronto, ON M5S 1 A8, Canada. ${ }^{11}$ Toronto Allergy and Asthma Centre, 123 Edward St, Toronto, ON M5G 1E2, Canada. ${ }^{12}$ Keenan Research Centre for Biomedical Science, St. Michael's Hospital, 30 Bond St, Toronto, ON M5B 1W8, Canada. ${ }^{13}$ Department of Surgery, School of Medicine, University of Toronto, 1 King's College Circle, \#3172, Toronto, ON M5S 1A8, Canada. ${ }^{14}$ Evidence Based Medical Educator Inc., 123 Edward St., Suite 920, Toronto, ON M5G 1E2, Canada.
\end{abstract}

\section{Acknowledgements}

The authors gratefully acknowledge the assistance of Jeff Alexander (medical writer), SNELL Medical Communication, in the preparation of this manuscript.

Support for the development of this paper was provided through arm's length educational funding from Novartis Pharmaceuticals Canada. Throughout the planning, development and editing of this paper, the authors exercised unrestricted, rigorous, scientific independence free of interference from any other party.

\section{Competing interests}

HK is Vice President of the Canadian Society of Allergy and Clinical Immunology and Co-chief Editor of Allergy, Asthma and Clinical Immunology. HK has received consulting fees and honoraria for continuing medical education from AstraZeneca, Aralez, Boehringer Ingelheim, CSL Behring, Kaleo, Merck, Novartis, Pediapharm, Sanofi, Shire and Teva. HK has received research funding from Sanofi and Novartis. AKE reports grants and other from Novartis, and AstraZeneca, during the conduct of the study. She also reports grants and other from Circassia Ltd, GlaxoSmithKline, Green Cross Pharmaceuticals, Merck,
Takeda, Meda, from Aralez, and grants from Sanofi, outside the submitted work. DF reports grants from Novartis, during the conduct of the study; other from AstraZeneca, Teva, Merck, and Sanofi, outside the submitted work. MN has no competing interests. KRC reports grants and personal fees from AstraZeneca, Boehringer Ingelheim, CSL Behring, Grifols, Sanofi, Genentech, Kamada, Roche, and Novartis; grants from Baxter, GlaxoSmithKline, and Amgen; personal fees from Merck, CIHR-GSK Research Chair in Respiratory Health Care Delivery, UHN, during the conduct of the study. JKL reports grants and personal fees from Novartis, Astrazeneca, and Sanofi, as well as personal fees from GSK, and Merck and personal fees from CSL during the conduct of the study.

\section{Availability of data and materials \\ Not applicable.}

\section{Consent for publication}

Not applicable.

\section{Ethics approval and consent to participate}

Not applicable.

\section{Funding}

Novartis Pharmaceuticals Canada, the funding sponsor, offered unrestricted support to the development of the manuscript and did not have any part in creating this document.

\section{Publisher's Note}

Springer Nature remains neutral with regard to jurisdictional claims in published maps and institutional affiliations.

Received: 11 July 2017 Accepted: 25 October 2017

Published online: 17 November 2017

\section{References}

1. World Health Organization. Asthma: fact sheet No 307. Updated November 2013. http://www.who.int/mediacentre/factsheets/fs307/ en. Accessed 21 Dec 2016.

2. Global Asthma Network. The global asthma report. 2014. Auckland: Global Asthma Network; 2014. http://www.globalasthmareport.org/ resources/Global_Asthma_Report_2014.pdf. Accessed 21 Dec 2016.

3. World Health Organization. Global surveillance, prevention and control of chronic respiratory diseases: a comprehensive approach. Geneva: WHO Press; 2007.

4. Statistics Canada. Health Fact Sheet 82-625-X: Asthma. 2014. http:// www.statcan.gc.ca/pub/82-625-x/2015001/article/14179-eng.htm. Accessed 21 Dec 2016.

5. Thomas EM. Recent trends in upper respiratory infections, ear infections and asthma among young Canadian children. Component of Statistics Canada Catalogue no. 82-003-X. 2010.

6. Wenzel SE, Schwartz LB, Langmack EL, et al. Evidence that severe asthma can be divided pathologically into two inflammatory subtypes with distinct physiologic and clinical characteristics. Am J Respir Crit Care Med. 1999;160(3):1001-8.

7. The ENFUMOSA Study Group. The ENFUMOSA cross-sectional European multicentre study of the clinical phenotype of chronic severe asthma. Eur Respir J. 2003;22(3):470-7.

8. Amelink M, de Groot JC, de Nijs SB, Lutter R, Zwinderman AH, Sterk PJ, ten Brinke A, Bel EH. Severe adult-onset asthma: a distinct phenotype. J Allergy Clin Immunol. 2013;132(2):336-41.

9. Chung KF, Wenzel SE, Brozek JL, ERS/ATS Task Force, et al. International ERS/ATS guidelines on definition, evaluation and treatment of severe asthma. Eur Respir J. 2014;43(4):343-73.

10. Barnes PJ, Woolcock AJ. Difficult asthma. Eur Respir J. 1998;12(5):1209-18.

11. Busse WW, Banks-Schlegel S, Wenzel SE. Pathophysiology of severe asthma. J Allergy Clin Immunol. 2000;106(6):1033-42. 
12. O'Byrne PM, Naji N, Gauvreau GM. Severe asthma: future treatments. Clin Exp Allergy. 2012;42:706-11.

13. Hekking PP, Wener RR, Amelink M, Zwinderman AH, Bouvy ML, Bel EH. The prevalence of severe refractory asthma. J Allergy Clin Immunol. 2015;135(4):896-902.

14. Von Bülow A, Kriegbaum M, Backer V, Porsbjerg C. The prevalence of severe asthma and low asthma control among Danish adults. J Allergy Clin Immunol Pract. 2014;2(6):759-67.

15. National Heart, Lung, and Blood Institute; National Asthma Education and Prevention Program. Expert Panel report 3: guidelines for the diagnosis and management of asthma. Full report 2007. Section 2: definition, pathophysiology and pathogenesis of asthma, and natural history of asthma.

16. Global Initiative for Asthma. Global strategy for asthma management and prevention. 2016. http://ginasthma.org/2016-gina-report-globalstrategy-for-asthma-management-and-prevention. Accessed 20 Jan 2017

17. Morton RW, Everard ML, Elphick HE. Adherence in childhood asthma: the elephant in the room. Arch Dis Child. 2014;99(10):949-53.

18. Solèr M, Matz J, Townley R, Buhl R, O'Brien J, Fox H, Thirlwell J, Gupta $\mathrm{N}$, Della Chioppa G. The anti-lgE antibody omalizumab reduces exacerbations and steroid requirement in allergic asthmatics. Eur Respir J. 2001;18(2):254-61.

19. Busse W, Corren J, Lanier BQ, McAlary M, Fowler-Taylor A, Della Cioppa G, van As A, Gupta N. Omalizumab, anti-lgE recombinant humanized monoclonal antibody, for the treatment of severe allergic asthma. J Allergy Clin Immunol. 2001;108(2):184-90.

20. Holgate ST, Chuchalin AG, Hébert J, Lötvalls J, Persson GB, Chung KF, Bousquet J, Kerstjens HA, Fox H, Thirlwell J, Cioppa GD. Efficacy and safety of a recombinant anti-immunoglobulin $\mathrm{E}$ antibody (omalizumab) in severe allergic asthma. Clin Exp Allergy. 2004;34(4):632-8.

21. Vignola AM, Humbert $M$, Bousquet J, Boulet LP, Hedgecock S, Blogg $\mathrm{M}$, Fox $\mathrm{H}$, Surrey K. Efficacy and tolerability of anti-immunoglobulin $\mathrm{E}$ therapy with omalizumab in patients with concomitant allergic asthma and persistent allergic rhinitis: SOLAR. Allergy. 2004;59:709-17.

22. Ayres JG, Higgins B, Chilvers ER, Ayre G, Blogg M, Fox H. Efficacy and tolerability of anti-immunoglobulin $E$ therapy with omalizumab in patients with poorly controlled (moderate-to-severe) allergic asthma. Allergy. 2004;59(7):701-8.

23. Genentech, Inc. Review of clinical safety data: omalizumab (Xolair ${ }^{\mathrm{TM}}$ ) BLA STN 103976/0.2003.

24. Bel EH, Wenzel SE, Thompson PJ, Prazma CM, Keene ON, Yancey SW, Ortega HG, Pavord ID, SIRIUS Investigators. Oral glucocorticoidsparing effect of mepolizumab in eosinophilic asthma. N Engl J Med. 2014;371(13):1189-97.

25. Ortega HG, Liu MC, Pavord ID, Brusselle GG, FitzGerald JM, Chetta A Humbert M, Katz LE, Keene ON, Yancey SW, Chanez P, MENSA Investigators. Mepolizumab treatment in patients with severe eosinophilic asthma. N Engl J Med. 2014;371(13):1198-207.

26. Pavord ID, Korn S, Howarth P, Bleecker ER, Buhl R, Keene ON, Ortega $H$, Chanez P. Mepolizumab for severe eosinophilic asthma (DREAM): a multicentre, double-blind, placebo-controlled trial. Lancet. 2012:380(9842):651-9.

27. Bjermer L, Lemiere C, Maspero J, Ciesielska M, O'Brien C, Zangrilli J. A randomized phase 3 study of the efficacy and safety of reslizumab in subjects with asthma with elevated eosinophils. Eur Respir J. 2014:44(Suppl 58):299.

28. Castro M, Mathur S, Hargreave F, Boulet LP, Xie F, Young J, Wilkins HJ, Henkel T, Nair P. Reslizumab for poorly controlled, eosinophilic asthma: a randomized, placebo-controlled study. Am J Respir Crit Care Med. 2011;184(10):1125-32.

29. Castro M, Zangrilli J, Wechsler ME, Bateman ED, Brusselle GG, Bardin P, Murphy K, Maspero JF, O'Brien C, Korn S. Reslizumab for inadequately controlled asthma with elevated blood eosinophil counts: results from two multicentre, parallel, double-blind, randomised, placebocontrolled, phase 3 trials. Lancet Respir Med. 2015;3(5):355-66.

30. Corren J, Weinstein S, Janka L, O'Brien C, Zangrilli J. A randomized phase 3 study of reslizumab efficacy in relation to blood eosinophil levels in patients with moderate to severe asthma. Eur Respir J. 2014;44(Suppl 58):4673.

31. Saunders KB. Origin of the word "asthma". Thorax. 1993;48:647.
32. Merriam-Webster Dictionary. https://www.merriam-webster.com/ dictionary/phenotype. Accessed 10 Jan 2017.

33. Kiley JP. Asthma phenotypes task force goals and objectives. Presented at the World Allergy Congress. December 8, 2009: Buenos Aires, Argentina.

34. Wenzel SE. Asthma phenotypes: the evolution from clinical to molecular approaches. Nat Med. 2012;18(5):716-25.

35. Bel EH. Clinical phenotypes of asthma. Curr Opin Pulm Med. 2004;10(1):44-50.

36. Borish L, Culp JA. Asthma: a syndrome composed of heterogeneous diseases. Ann Allergy Asthma Immunol. 2008;101(1):1-8.

37. Lockey RF. Asthma phenotypes: an approach to the diagnosis and treatment of asthma (editorial). J Allergy Clin Immunol Pract. 2014;2(6):682-5.

38. Haldar P, Pavord ID, Shaw DE, Berry MA, Thomas M, Brightling CE, Wardlaw AJ, Green RH. Cluster analysis and clinical asthma phenotypes. Am J Respir Crit Care Med. 2008;178(3):218-24

39. Moore WC, Fitzpatric AM, Li X, Hastie AT, Li H, Meyers DA, Bleecker ER. Clinical heterogeneity in the severe asthma research program. Ann Am Thorac Soc. 2013;10(Suppl):S118-24.

40. Asthma and Allergy Foundation of America. Allergens and allergic asthma. http://www.aafa.org/page/allergic-asthma.aspx. Accessed 10 Jan 2017.

41. Arbes SJ Jr, Gergen PJ, Vaughn B, Zeldin DC. Asthma cases attributable to atopy: results from the Third National Health and Nutrition Examination Survey. J Allergy Clin Immunol. 2007;120(5):1139-45.

42. Asthma and Allergy Foundation of America. Allergens and allergic asthma. http://www.aafa.org/page/allergic-asthma.aspx. Accessed 10 Feb 2017.

43. Schatz M, Rosenwasser L. The allergic asthma phenotype. J Allergy Clin Immunol Pract. 2014;2(6):645-8.

44. Haselkorn T, TENOR Study Group, et al. Allergy, total serum immuno-

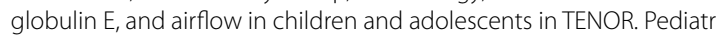
Allergy Immunol. 2010;21(8):1157-65.

45. Covar RA, Spahn JD, Murphy JR, Szefler SJ. Progression of asthma measured by lung function in the childhood asthma management program. Am J Respir Crit Care Med. 2004;170:234-41.

46. Szefler SJ, Wenzel S, Brown R, Erzurum SC, Fahy JV, Hamilton RG, Hunt JF, Kita H, Liu AH, Panettieri RA Jr, Schleimer RP, Minnicozzi M. Asthma outcomes: biomarkers. J Allergy Clin Immunol. 2012;129(3 Suppl):S9-23.

47. Brusselle GG, Maes T, Bracke KR. Bedside to bench: eosinophilic airway inflammation in nonallergic asthma. Nat Med. 2013;19(8):977-9.

48. Amin K, Janson C, Boman G, Venge P. The extracellular deposition of mast cell products is increased in hypertrophic airways smooth muscles in allergic asthma but not in nonallergic asthma. Allergy. 2005;60(10):1241-7

49. Walker C, Bode E, Boer L, Hansel TT, Blaser K, Virchow J-C Jr. Allergic and nonallergic asthmatics have distinct patterns of T-cell activation and cytokine production in peripheral blood and bronchoalveolar lavage. Am Rev Respir Dis. 1992;146(1):109-15.

50. Romanet-Manent S, Charpin D, Magnan A, Lanteaume A, Vervloet D, EGEA Cooperative Group. Allergic vs nonallergic asthma: what makes the difference? Allergy. 2002;57(7):607-13.

51. Peters SP. Asthma phenotypes: nonallergic (intrinsic) asthma. J Allergy Clin Immunol Pract. 2014;2(6):650-2.

52. Lötvall J, Akdis CA, Bacharier LB, Bjermer L, Casale TB, Custovic A, Lemanske RF Jr, Wardlaw AJ, Wenzel SE, Greenberger PA. Asthma endotypes: a new approach to classification of disease entities within the asthma syndrome. J Allergy Clin Immunol. 2011;127(2):355-60.

53. Fajt ML, Wenzel SE. Asthma phenotypes and the use of biologic medications in asthma and allergic disease: the next steps toward personalized care. J Allergy Clin Immunol. 2015;135(2):299-310.

54. Buhl R, Korn S, Menzies-Gow A, Aubier M, Chapman KR, Canonica GW, Picado C, Martin N, Escobar RA, Korom S, Hanania NA. Assessing biomarkers in a real-world severe asthma study (ARIETTA). Respir Med. 2016;115:7-12.

55. Fleming L, Murray C, Bansal AT, Hashimoto S, Bisgaard H, Bush A, Frey U, Hedlin G, Singer F, van Aalderen WM, Vissing NH, Zolkipli Z, Selby A, Fowler S, Shaw D, Chung KF, Sousa AR, Wagers S, Corfield J, Pandis I, Rowe A, Formaggio E, Sterk PJ, Roberts G, U-BIOPREDStudy Group. The burden of severe asthma in childhood and adolescence: results from the paediatric U-BIOPRED cohorts. Eur Respir J. 2015;46(5):1322-33. 
56. Loza MJ, Djukanovic R, Chung KF, Horowitz D, Ma K, Branigan P, Barnathan ES, Susulic VS, Silkoff PE, Sterk PJ, Baribaud F, ADEPT (Airways Disease Endotyping for Personalized Therapeutics) and U-BIOPRED (Unbiased Biomarkers for the Prediction of Respiratory Disease Outcome Consortium) investigators. Validated and longitudinally stable asthma phenotypes based on cluster analysis of the ADEPT study. Respir Res. 2016;17(1):165

57. Silkoff PE, Strambu I, Laviolette M, Singh D, FitzGerald JM, Lam S, Kelsen S, Eich A, Ludwig-Sengpiel A, Hupp GC, Backer V, Porsbjerg C, Girodet PO, Berger P, Leigh R, Kline JN, Dransfield M, Calhoun W, Hussaini A, Khatri S, Chanez P, Susulic VS, Barnathan ES, Curran M, Das AM, Brodmerkel C, Baribaud F, Loza MJ. Asthma characteristics and biomarkers from the airways disease endotyping for personalized therapeutics (ADEPT) longitudinal profiling study. Respir Res. 2015;16:142.

58. Burrows B, Martinez FD, Halonen M, Barbee RA, Cline MG. Association of asthma with serum IgE levels and skin-test reactivity to allergens. N Engl J Med. 1989;320(5):271-7.

59. Matsui EC, Sampson HA, Bahnson HT, Gruchalla RS, Pongracic JA, Teach SJ, Gergen PJ, Bloomberg GR, Chmiel JF, Liu AH, Kattan M, Sorkness CA, Steinbach SF, Story RE, Visness CM, Inner-city Asthma Consortium. Allergen-specific IgE as a biomarker of exposure plus sensitization in inner-city adolescents with asthma. Allergy. 2010;65(11):1414-22.

60. Holgate S, Smith N, Massanari M, Jimenez P. Effects of omalizumab on markers of inflammation in patients with allergic asthma. Allergy. 2009;64(12):1728-36.

61. Platts-Mills TAE. The role of immunoglobulin $E$ in allergy and asthma. Am J Respir Crit Care Med. 2001;164(8 Pt 2):S1-5.

62. Holgate S, Casale T, Wenzel S, Bousquet J, Deniz Y, Reisner C. The antiinflammatory effects of omalizumab confirm the central role of lgE in allergic inflammation. J Allergy Clin Immunol. 2005;115(3):459-65.

63. Stone KD, Prussin C, Metcalfe DD. IgE, mast cells, basophils, and eosinophils. J Allergy Clin Immunol. 2010;125(2 Suppl 2):S73-80.

64. Ahmad Al Obaidi AH, Mohamed Al Samarai AG, Yahya Al Samarai AK, Al Janabi JM. The predictive value of IgE as biomarker in asthma. J Asthma. 2008;45(8):654-63.

65. Patelis A, Gunnbjörnsdottir M, Malinovschi A, Matsson P, Onell A, Högman M, Alving K, Janson C. Population-based study of multiplexed IgE sensitization in relation to asthma, exhaled nitric oxide, and bronchial responsiveness. J Allergy Clin Immunol. 2012;130(2):397-402.e2.

66. Caudri D, Wijga AH, Hoekstra MO, Kerkhof M, Koppelman GH, Brunekreef B, Smit HA, de Jongste JC. Prediction of asthma in symptomatic preschool children using exhaled nitric oxide, Rint and specific IgE. Thorax. 2010;65(9):801-7.

67. Gerald JK, Gerald LB, Vasquez MM, Morgan WJ, Boehmer SJ, Lemanske RF Jr, et al. Markers of differential response to inhaled corticosteroid treatment among children with mild persistent asthma. J Allergy Clin Immunol Pract. 2015;3(4):540-6.

68. Simpson A, Soderstrom L, Ahlstedt S, Murray CS, Woodcock A, Custovic A. IgE antibody quantification and the probability of wheeze in preschool children. J Allergy Clin Immunol. 2005;116(4):744-9.

69. Wickman M, Ahlstedt S, Lilja G, van Hage Hamsten M. Quantification of IgE antibodies simplifies the classification of allergic diseases in 4-yearold children. A report from the prospective birth cohort study-BAMSE. Pediatr Allergy Immunol. 2003;14(6):441-7.

70. Sears MR, Burrows B, Flannery EM, Herbison GP, Hewitt CJ, Holdaway MD. Relation between airway responsiveness and serum IgE in children with asthma and in apparently normal children. N Engl J Med. 1991;325(15):1067-71.

71. Resnick MB, Weller PF. Mechanisms of eosinophil recruitment. Am J Respir Cell Mol Biol. 1993;8(4):349-55.

72. de Groot JC, Storm H, Amelink M, de Nijs SB, Eichhorn E, Reitsma $\mathrm{BH}, \mathrm{Bel}$ EHD, Ten Brinke A. Clinical profile of patients with adultonset eosinophilic asthma. ERJ Open Res. 2016;2(2). pii: 00100-2015. doi:10.1183/23120541.00100-2015

73. Louis R, Lau LCK, Bron AO, Roldaan AC, Radermecker M, Djukanovic R. The relationship between airways inflammation and asthma severity. Am J Respir Crit Care Med. 2000;161(1):9-16.

74. Miranda C, Busacker A, Balzar S, Trudeau J, Wenzel SE. Distinguishing severe asthma phenotypes: role of age at onset and eosinophilic inflammation. J Allergy Clin Immunol. 2004;113(1):101-8.
75. Bousquet J, Chanez P, Lacoste JY, Barnéon G, Ghavanian N, Enander I, Venge P, Ahlstedt S, Simony-Lafontaine J, Godard P. Eosinophilic inflammation in asthma. N Engl J Med. 1990;323(15):1033-9.

76. Woodruff PG, Khashayar R, Lazarus SC, Janson S, Avila P, Boushey HA, Segal M, Fahy JV. Relationship between airway inflammation, hyperresponsiveness, and obstruction in asthma. J Allergy Clin Immunol. 2001;108(5):753-8.

77. Kamath AV, Pavord ID, Ruparelia PR, Chilvers ER. Is the neutrophil the key effector cell in severe asthma? Thorax. 2005;60(7):529-30.

78. Schleich FN, Chevremont A, Paulus V, Henket M, Manise M, Seidel L, Louis R. Importance of concomitant local and systemic eosinophilia in uncontrolled asthma. Eur Respir J. 2014;44(1):97-108.

79. Fahy JV. Eosinophilic and neutrophilic inflammation in asthma: insights from clinical studies. Proc Am Thorac Soc. 2009;6(3):256-9.

80. Shaw DE, Berry MA, Hargadon B, McKenna S, Shelley MJ, Green RH, Brightling CE, Wardlaw AJ, Pavord ID. Association between neutrophilic airway inflammation and airflow limitation in adults with asthma. Chest. 2007:132(6):1871-5.

81. Fahy JV, Kim KW, Liu J, Boushey HA. Prominent neutrophilic inflammation in sputum from subjects with asthma exacerbation. J Allergy Clin Immunol. 1995;95(4):843-52.

82. Ordoñez CL, Shaughnessy TE, Matthay MA, Fahy JV. Increased neutrophil numbers and IL-8 levels in airway secretions in acute severe asthma: clinical and biologic significance. Am J Respir Crit Care Med. 2000;161(4 Pt 1):1185-90.

83. Trevor JL, Deshane JS. Refractory asthma: mechanisms, targets, and therapy. Allergy. 2014;69(7):817-27.

84. Rosenberg HF, Phipps S, Foster PS. Eosinophil trafficking in allergy and asthma. J Allergy Clin Immunol. 2007;119(6):1303-10.

85. Greenfeder S, Umland SP, Cuss FM, Chapman RW, Egan RW. Th2 cytokines and asthma: the role of interleukin-5 in allergic eosinophilic disease. Respir Res. 2001;2(2):71-9.

86. Bradding $\mathrm{P}, \mathrm{Holgate} \mathrm{ST}$. The mast cell as a source of cytokines in asthma. Ann N Y Acad Sci. 1996;796(1):272-81.

87. Brightling CE, Symon FA, Holgate ST, Wardlaw AJ, Pavord ID, Bradding P. Interleukin-4 and -13 expression is co-localized to mast cells within the airway smooth muscle in asthma. Clin Exp Allergy. 2003;33(12):1711-6.

88. Robinson DS. The role of the mast cell in asthma: induction of airway hyperresponsiveness by interaction with smooth muscle? J Allergy Clin Immunol. 2004;114(1):58-65.

89. Clutterbuck EJ, Hirst EM, Sanderson CJ. Human interleukin-5 (IL-5) regulates the production of eosinophils in human bone marrow cultures: comparison and interaction with IL-1, IL-3, IL-6, and GMCSF. Blood. 1989:3(6):1504-12.

90. Sitkauskiene B, Johansson AK, Sergejeva S, Lundin S, Sjöstrand M, Lötvall J. Regulation of bone marrow and airway CD34+ eosinophils by interleukin-5. Am J Respir Cell Mol Biol. 2004;30(3):367-78.

91. Hirai K, Yamaguchi M, Misaki Y, Takaishi T, Ohfa K, Morita Y, Ito K, Miyamoto T. Enhancement of human basophil histamine release by interleukin 5. J Exp Med. 1990;172:1525-8.

92. Bagnasco D, Ferrando M, Varricchi G, Passalacqua G, Canonica GW. A critical evaluation of anti-IL-13 and anti-IL-4 strategies in severe asthma. Int Arch Allergy Immunol. 2016;170(2):122-31.

93. Munitz A, Brandt EB, Mingler M, Finkelman FD, Rothenberg ME. Distinct roles for IL-13 and IL-4 via IL-13 receptor alpha1 and the type II IL-4 receptor in asthma pathogenesis. Proc Natl Acad Sci USA. 2008;105(20):7240-5.

94. D’Agostino B, Gallelli L, Falciani M, Di Pierro P, Rossi F, Filippelli A, Rossi F. Endothelin-1 induced bronchial hyperresponsiveness in the rabbit: an ET(A) receptor-mediated phenomenon. Naunyn Schmiedebergs Arch Pharmacol. 1999;360(6):665-9.

95. Corren J. Role of interleukin-13 in asthma. Curr Allergy Asthma Rep. 2013;13(5):415-20.

96. Minshall E, Chakir J, Laviolette M, Molet S, Zhu Z, Olivenstein R, Elias JA, Hamid Q. IL-11 expression is increased in severe asthma: association with epithelial cells and eosinophils. J Allergy Clin Immunol. 2000;105(2 Pt 1):232-8

97. Li H, Rostami A. IL-9: basic biology, signaling pathways in CD4+ T cells and implications for autoimmunity. J Neuroimmune Pharmacol. 2010:5(2):198-209. 
98. Barnes PJ. The cytokine network in asthma and chronic obstructive pulmonary disease. J Clin Investig. 2008;118(11):3546-56.

99. Eklund KK, Ghildyal N, Austen KF, Stevens RL. Induction by IL-9 and suppression by IL-3 and IL-4 of the levels of chromosome 14-derived transcripts that encode late-expressed mouse mast cell proteases. J Immunol. 1993;151(8):4266-73.

100. Chakir J, Shannon J, Molet S, Fukakusa M, Elias J, Laviolette M, Boulet $L P$, Hamid Q. Airway remodeling-associated mediators in moderate to severe asthma: effect of steroids on TGF-beta, IL-11, IL-17, and type I and type III collagen expression. J Allergy Clin Immunol. 2003;111(6):1293-8.

101. Barczyk A, Pierzchala W, Sozañska E. Interleukin-17 in sputum correlates with airway hyperresponsiveness to methacholine. Respir Med. 2003;97(6):726-33.

102. Pène J, Chevalier S, Preisser L, Vénéreau E, Guilleux MH, Ghannam S, Molès JP, Danger Y, Ravon E, Lesaux S, Yssel H, Gascan H. Chronically inflamed human tissues are infiltrated by highly differentiated Th 17 lymphocytes. J Immunol. 2008;180(11):7423-730.

103. Oda N, Canelos PB, Essayan DM, Plunkett BA, Myers AC, Huang SK. Interleukin-17F induces pulmonary neutrophilia and amplifies antigen-induced allergic response. Am J Respir Crit Care Med. 2005;171(1):12-8.

104. Hymowitz SG, Filvaroff EH, Yin JP, Lee J, Cai L, Risser P, Maruoka M, Mao W, Foster J, Kelley RF, Pan G, Gurney AL, de Vos AM, Starovasnik MA. IL-17s adopt a cystine knot fold: structure and activity of a novel cytokine, IL-17F, and implications for receptor binding. EMBO J. 2001;20(19):5332-41.

105. Walker JA, Barlow JL, McKenzie AN. Innate lymphoid cells_-how did we miss them? Nat Rev Immunol. 2013;13(2):75-87.

106. Komai-Koma M, Xu D, Li Y, McKenzie AN, McInnes IB, Liew FY. IL-33 is a chemoattractant for human Th2 cells. Eur J Immunol. 2007;37(10):2779-86.

107. Fort MM, Cheung J, Yen D, Li J, Zurawski SM, Lo S, Menon S, Clifford T, Hunte B, Lesley R, Muchamuel T, Hurst SD, Zurawski G, Leach MW, Gorman DM, Rennick DM. IL-25 induces IL-4, IL-5, and IL-13 and Th2associated pathologies in vivo. Immunity. 2001;15(6):985-95.

108. Oboki K, Nakae S, Matsumoto K, Saito H. IL-33 and airway inflammation. Allergy Asthma Immunol Res. 2011;3(2):81-8.

109. Zhao Y, Yang J, Gao YD, Guo W. Th17 immunity in patients with allergic asthma. Int Arch Allergy Immunol. 2010;151(4):297-307.

110. Besnard AG, Sabat R, Dumoutier L, Renauld JC, Willart M, Lambrecht B, Teixeira MM, Charron S, Fick L, Erard F, Warszawska K, Wolk K, Quesniaux V, Ryffel B, Togbe D. Dual role of IL-22 in allergic airway inflammation and its cross-talk with IL-17A. Am J Respir Crit Care Med. 2011;183(9):1153-63.

111. Takahashi K, Hirose K, Kawashima S, Niwa Y, Wakashin H, Iwata A, Tokoyoda K, Renauld JC, Iwamoto I, Nakayama T, Nakajima H. IL-22 attenuates IL-25 production by lung epithelial cells and inhibits antigen-induced eosinophilic airway inflammation. J Allergy Clin Immunol. 2011;128(5):1067-76.

112. Manel N, Unutmaz D, Littman DR. The differentiation of human $\mathrm{T}(\mathrm{H})-17$ cells requires transforming growth factor-beta and induction of the nuclear receptor RORgammat. Nat Immunol. 2008;9(6):641-9.

113. Volpe E, Servant N, Zollinger R, Bogiatzi SI, Hupé P, Barillot E, Soumelis $V$. A critical function for transforming growth factor-beta, interleukin 23 and proinflammatory cytokines in driving and modulating human T(H)-17 responses. Nat Immunol. 2008;9(6):650-7.

114. Yen D, Cheung J, Scheerens H, Poulet F, McClanahan T, McKenzie B, Kleinschek MA, Owyang A, Mattson J, Blumenschein W, Murphy E, Sathe M, Cua DJ, Kastelein RA, Rennick D. IL-23 is essential for T cellmediated colitis and promotes inflammation via IL-17 and IL-6. J Clin Investig. 2006;1 16(5):1310-6.

115. Robinson KM, Manni ML, Biswas PS, Alcorn JF. Clinical consequences of targeting $\mathrm{IL}-17$ and TH17 in autoimmune and allergic disorders. Curr Allergy Asthma Rep. 2013;13(6):587-95.

116. Li Y, Hua S. Mechanisms of pathogenesis in allergic asthma: role of interleukin-23. Respirology. 2014;19(5):663-9.

117. Takayama G, Arima K, Kanaji T, Toda S, Tanaka H, Shoji S, McKenzie AN, Nagai $\mathrm{H}$, Hotokebuchi T, Izuhara K. Periostin: a novel component of subepithelial fibrosis of bronchial asthma downstream of IL-4 and IL-13 signals. J Allergy Clin Immunol. 2006;1 18(1):98-104.
118. Woodruff PG, Boushey HA, Dolganov GM, Barker CS, Yang YH, Donnelly S, Ellwanger A, Sidhu SS, Dao-Pick TP, Pantoja C, Erle DJ, Yamamoto KR, Fahy JV. Genome-wide profiling identifies epithelial cell genes associated with asthma and with treatment response to corticosteroids. Proc Natl Acad Sci USA. 2007:104(40):15858-63.

119. Yuyama N, Davies DE, Akaiwa M, Matsui K, Hamasaki Y, Suminami Y, Yoshida NL, Maeda M, Pandit A, Lordan JL, Kamogawa Y, Arima K, Nagumo F, Sugimachi M, Berger A, Richards I, Roberds SL, Yamashita T, Kishi F, Kato H, Arai K, Ohshima K, Tadano J, Hamasaki N, Miyatake S, Sugita Y, Holgate ST, Izuhara K. Analysis of novel disease-related genes in bronchial asthma. Cytokine. 2002;19(6):287-96.

120. Blanchard C, Mingler MK, McBride M, Putnam PE, Collins MH, Chang G, Stringer K, Abonia JP, Molkentin JD, Rothenberg ME. Periostin facilitates eosinophil tissue infiltration in allergic lung and esophageal responses. Mucosal Immunol. 2008;1(4):289-96.

121. Uchida M, Shiraishi H, Ohta S, Arima K, Taniguchi K, Suzuki S, Okamoto M, Ahlfeld SK, Ohshima K, Kato S, Toda S, Sagara H, Aizawa H, Hoshino T, Conway SJ, Hayashi S, Izuhara K. Periostin, a matricellular protein, plays a role in the induction of chemokines in pulmonary fibrosis. Am J Respir Cell Mol Biol. 2012:46:677-86.

122. Izuhara $\mathrm{K}$, Ohta S, Ono J. Using periostin as a biomarker in the treatment of asthma. Allergy Asthma Immunol Res. 2016;8(6):491-8.

123. Schade J, Stephan M, Schmiedl A, et al. Regulation of expression and function of dipeptidyl peptidase 4 (DP4), DP8/9, and DP10 in allergic responses of the lung in rats. J Histochem Cytochem. 2008;56(2):147-55.

124. Stephan M, Suhling H, Schade J, et al. Effects of dipeptidyl peptidase-4 inhibition in an animal model of experimental asthma: a matter of dose, route, and time. Physiol Rep. 2013;1(5):e00095.

125. Zhang T, Urbanek C, Burchard EG, Chu H, Seibold MA. The asthma biomarker dipeptidyl peptidase 4 (dpp4) is IL-13 inducible in airway epithelial cells and inhibits rhinovirus infection. In: Presented at the American Thoracic Society 2014 International Conference. May 16-21, 2014: San Diego, California. Abstract A4875.

126. Shiobara T, Chibana K, Watanabe T, Arai R, Horigane Y, Nakamura Y, Hayashi Y, Shimizu Y, Takemasa A, Ishii Y. Dipeptidyl peptidase- 4 is highly expressed in bronchial epithelial cells of untreated asthma and it increases cell proliferation along with fibronectin production in airway constitutive cells. Respir Res. 2016;17:28.

127. Kim SH, Choi H, Yoon MG, Ye YM, Park HS. Dipeptidyl-peptidase 10 as a genetic biomarker for the aspirin-exacerbated respiratory disease phenotype. Ann Allergy Asthma Immunol. 2015;114(3):208-13.

128. Lougheed MD, Lemiere C, Ducharme FM, Licskai C, Dell SD, Rowe BH, FitzGerald M, Leigh R, Watson W, Boulet L-P, Canadian Thoracic Society Asthma Clinical Assembly. Canadian Thoracic Society 2012 guideline update: diagnosis and management of asthma in preschoolers, children and adults. Can Respir J. 2012;19(2):127-64.

129. Good JT Jr, Kolakowski CA, Groshong SD, Murphy JR, Martin RJ. Refractory asthma: importance of bronchoscopy to identify phenotypes and direct therapy. Chest. 2012;141(3):599-606.

130. Brasier AR, Victor S, Ju H, Busse WW, Curran-Everett D, Bleecker E, Castro M, Chung KF, Gaston B, Israel E, Wenzel SE, Erzurum SC, Jarjour NN, Calhoun WJ. Predicting intermediate phenotypes in asthma using bronchoalveolar lavage-derived cytokines. Clin TransI Sci. 2010;3(4):147-57.

131. Jiang $K$, Chen H-B, Wang Y, Lin J-H, Hu Y, Fang Y-R. Changes in interleukin-17 and transforming growth factor beta 1 levels in serum and bronchoalveolar lavage fluid and their clinical significance among children with asthma. Transl Pediatr. 2013;2(4):154-9.

132. Connett GJ. Bronchoalveolar lavage. Paediatr Respir Rev. 2000;1 (1):52-6.

133. Elston WJ, Whittaker AJ, Khan LN, Flood-Page P, Ramsay C, Jeffrey PK, Barnes NC. Safety of research bronchoscopy, biopsy and bronchoalveolar lavage in asthma. Eur Respir J. 2004;24(3):375-7.

134. Vargas JE, Porto BN, Puga R, Stein RT, Pitrez PM. Identifying a biomarker network for corticosteroid resistance in asthma from bronchoalveolar lavage samples. Mol Biol Rep. 2016;43(7):697-710.

135. Moore WC, Evans MD, Bleecker ER, Busse WW, Calhoun WJ, Castro M, Chung KF, Erzurum SP, Curran-Everett D, Dweik RA, Gaston B, Hew M, Israel E, Mayse ML, Pascual RM, Peters SP, Silveira L, Wenzel SE, Jarjour NN. Safety of investigative bronchoscopy in the Severe Asthma Research Program. J Allergy Clin Immunol. 2011;128(2):328-36. 
136. Heinzerling L, Mari A, Bergmann KC, et al. The skin prick test —European standards. Clin Transl Allergy. 2013;3(1):3.

137. Pesonen M, Kallio MJ, Siimes MA, Ranki A. Allergen skin prick testing in early childhood: reproducibility and prediction of allergic symptoms into early adulthood. J Pediatr. 2015;166(2):401-6.

138. Buyuktiryaki B, Sahiner UM, Karabulut E, Cavkaytar O, Tuncer A, Sekerel BE. Optimizing the use of a skin prick test device on children. Int Arch Allergy Immunol. 2013;162(1):65-70.

139. Fatteh S, Rekkerth DJ, Hadley JA. Skin prick/puncture testing in North America: a call for standards and consistency. Allergy Asthma Clin Immunol. 2014:10(1):44.

140. Wandalsen GF, Solé D, Bacharier LB. Identification of infants and preschool children at risk for asthma: predictive scores and biomarkers. Curr Opin Allergy Clin Immunol. 2016;16(2):120-6.

141. Choi IS, Koh YI, Koh JS, Lee MG. Sensitivity of the skin prick test and specificity of the serum-specific lgE test for airway responsiveness to house dust mites in asthma. J Asthma. 2005;42(3):197-202.

142. Cox L, Williams B, Sicherer S, Oppenheimer J, Sher L, Hamilton R, Golden D. Pearls and pitfalls of allergy diagnostic testing: report from the American College of Allergy, Asthma and Immunology/American Academy of Allergy, Asthma and Immunology Specific IgE Test Task Force. Ann Allergy Asthma Immunol. 2008;101(6):580-92.

143. Freidhoff $L R$, Marsh DG. Relationship among asthma, serum lgE levels and skin test sensitivity to inhaled allergens. Int Arch Allergy Immunol. 1993;100(4):355-61.

144. Lama M, Chatterjee M, Chaudhuri TK. Total serum immunoglobulin E in children with asthma. Indian J Clin Biochem. 2013;28(2):197-200.

145. Johansson SGO, Bennich H. Serum immunoglobulin (lgE) levels in asthma. Thorax. 1969;24(4):510.

146. Kerkhof M, Droste JHJ, de Monchy JGR, Schouten JP, Rijcken B, Dutch ECRHS Group. Distribution of total serum IgE and specific lgE to common aeroallergens by sex and age, and their relationship to each other in a random sample of the Dutch general population aged 20-70 years. Allergy. 1996;51(11):770-6.

147. Martins TB, Bandhauer ME, Bunker AM, Roberts WL, Hill HR. New childhood and adult reference intervals for total IgE. J Allergy Clin Immunol. 2014;133(2):589-91

148. Mediaty A, Neuber K. Total and specific serum IgE decreases with age in patients with allergic rhinitis, asthma and insect allergy but not in patients with atopic dermatitis. Immun Ageing. 2005;2(1):9.

149. Wagener AH, de Nijs SB, Lutter R, Sousa AR, Weersink EJ, Bel EH, Sterk PJ. External validation of blood eosinophils, $\mathrm{FE}(\mathrm{NO})$ and serum periostin as surrogates for sputum eosinophils in asthma. Thorax. 2015;70(2):115-20.

150. Woodruff PG, Modrek B, Choy DF, Jia G, Abbas AR, Ellwanger A, Koth LL, Arron JR, Fahy JV. T-helper type 2-driven inflammation defines major subphenotypes of asthma. Am J Respir Crit Care Med. 2009;180(5):388-95.

151. Katz LE, Gleich GJ, Hartley BF, Yancey SW, Ortega HG. Blood eosinophil count is a useful biomarker to identify patients with severe eosinophilic asthma. Ann Am Thorac Soc. 2014;1 1(4):531-6.

152. Malinovschi A, Fonseca JA, Jacinto T, Alving K, Janson C. Exhaled nitric oxide levels and blood eosinophil counts independently associate with wheeze and asthma events in National Health and Nutrition Examination Survey subjects. J Allergy Clin Immunol. 2013;132(4):821-7.

153. Zeiger RS, Schatz M, Dalal AA, Chen W, Sadikova E, Suruki RY, Kawatkar AA, Qian L. Blood eosinophil count and outcomes in severe uncontrolled asthma: a prospective study. J Allergy Clin Immunol Pract. 2017;5(1):144-53.

154. Lönnkvist K, Hellman C, Lundahl J, Halldén G, Hedlin G. Eosinophil markers in blood, serum, and urine for monitoring the clinical course in childhood asthma: impact of budesonide treatment and withdrawal. $J$ Allergy Clin Immunol. 2001;107(5):812-7.

155. Young B, Lowe JO, Stevens A, Heath JW. Wheater's functional histology. 5th ed. London: Elsevier Ltd.; 2006.

156. Austin D, Pouliquen I, Yancey S, Bleeker E. A blood eosinophil count of greater than 150 cells/ $\mu$ l predicts sputum eosinophilia $\geq 3 \%$ in patients with severe asthma with other markers of inflammatory lung disease. In: Presented at the American Thoracic Society 2016 international conference. May 13-18, 2016. San Francisco, California. Abstract A4338.
157. Nadif R, Siroux V, Oryszczyn MP, Ravault C, Pison C, Pin I, Kauffmann F, Epidemiological study on the Genetics and Environment of Asthma (EGEA). Heterogeneity of asthma according to blood inflammatory patterns. Thorax. 2009;64(5):374-80.

158. Price DB, Rigazio A, Campbell JD, Bleecker ER, Corrigan CJ, Thomas M, Wenzel SW, Wilson AM, Small MB, Gopalan G, Ashtom VL, Burden A, Hillyer EV, Kerkhof M, Pavord ID. Blood eosinophil count and prospective annual asthma disease burden: a UK cohort study. Lancet Respir Med. 2015:3(11):849-58.

159. Wardzyńska A, Makowska JS, Pawełczyk M, Piechota-Polańczyk A, Kurowski M, Kowalski ML. Periostin in exhaled breath condensate and in serum of asthmatic patients: relationship to upper and lower airway disease. Allergy Asthma Immunol Res. 2017;9(2):126-32.

160. Nagasaki T, Matsumoto H, Kanemitsu Y, Izuhara K, Tohda Y, Kita H, Horiguchi T, Kuwabara K, Tomii K, Otsuka K, Fujimura M, Ohkura N, Tomita K, Yokoyama A, Ohnishi H, Nakano Y, Oguma T, Hozawa S, Ito I, Oguma T, Inoue H, Tajiri T, Iwata T, Izuhara Y, Ono J, Ohta S, Yokoyama T, Niimi A, Mishima M. Integrating longitudinal information on pulmonary function and inflammation using asthma phenotypes. J Allergy Clin Immunol. 2014;133(5):1474-7.

161. Jia G, Erickson RW, Choy DF, Mosesova S, Wu LC, Solberg OD, Shikotra A, Carter R, Audusseau S, Hamid Q, Bradding P, Fahy JV, Woodruff PG, Harris JM, Arron JR, Bronchoscopic Exploratory Research Study of Biomarkers in Corticosteroid-refractory Asthma (BOBCAT) Study Group. Periostin is a systemic biomarker of eosinophilic airway inflammation in asthmatic patients. J Allergy Clin Immunol. 2012;130(3):647-54.

162. Corren J, Lemanske RF, Hanania NA, Korenblat PE, Parsey MV, Arron JR, Harris JM, Scheerens H, Wu LC, Su Z, Mosesova S, Eisner MD, Bohen SP, Matthews JG. Lebrikizumab treatment in adults with asthma. N Engl J Med. 2011;365(12):1088-98.

163. Noonan M, Korenblat P, Mosesova S, Scheerens H, Arron JR, Zheng Y, Putnam WS, Parsey MV, Bohen SP, Matthews JG. Dose-ranging study of lebrikizumab in asthmatic patients not receiving inhaled steroids. J Allergy Clin Immunol. 2013;132(3):567-74.

164. Scheerens H, Arron JR, Zheng Y, Putnam WS, Erickson RW, Choy DF, Harris JM, Lee J, Jarjour NN, Matthews JG. The effects of lebrikizumab in patients with mild asthma following whole lung allergen challenge. Clin Exp Allergy. 2014;44(1):38-46.

165. Reddel HK, Taylor DR, Bateman ED, Boulet LP, Boushey HA, Busse WW Casale TB, Chanez P, Enright PL, Gibson PG, de Jongste JC, Kerstjens HA, Lazarus SC, Levy ML, O'Byrne PM, Partridge MR, Pavord ID, Sears MR, Sterk PJ, Stoloff SW, Sullivan SD, Szefler SJ, Thomas MD, Wenzel SE, American Thoracic Society/European Respiratory Society Task Force on Asthma Control and Exacerbations. An official American Thoracic Society/European Respiratory Society statement: asthma control and exacerbations: standardizing endpoints for clinical asthma trials and clinical practice. Am J Respir Crit Care Med. 2009;180(1):59-99.

166. Simpson JL, Scott R, Boyle MJ, Gibson PG. Inflammatory subtypes in asthma: assessment and identification using induced sputum. Respirology. 2006;11(1):54-61.

167. Pizzichini E, Pizzichini M, Efthimiadis A, Evans S, Morris MM, Squillace D, Gleich GJ, Dolovich J, Hargreave FE. Indices of airway inflammation in induced sputum: reproducibility and validity of cell and fluid-phase measurements. Am J Respir Crit Care Med. 1996:154(2 Pt 1):308-17.

168. Djukanovic R, Sterk PJ, Fahy JV, Hargreave FE. Standardised methodology of sputum induction and processing. Eur Respir J. 2002;20(37 Suppl):1s-55s.

169. Davidson WJ, The S, Leigh R. Establishing a normal range for induced sputum cell counts in Western Canada. Can Respir J. 2013;20(6):424-8.

170. Pin I, Freitag AP, O'Byrne PM, Girgis-Gabardo A, Watson RM, Dolovich J, Denburg JA, Hargreave FE. Changes in the cellular profile of induced sputum after allergen-induced asthmatic responses. Am Rev Respir Dis. 1992;145(6):1265-9.

171. Pizzichini MM, Pizzichini E, Clelland L, Efthimiadis A, Mahony J, Dolovich J, Hargreave FE. Sputum in severe exacerbations of asthma: kinetics of inflammatory indices after prednisone treatment. Am J Respir Crit Care Med. 1997;155(5):1501-8.

172. Petsky HL, Cates CJ, Lasserson TJ, Li AM, Turner C, Kynaston JA, Chang AB. A systematic review and meta-analysis: tailoring asthma treatment 
on eosinophilic markers (exhaled nitric oxide or sputum eosinophils). Thorax. 2012;67(3):199-208

173. Bobolea I, Barranco P, Del Pozo V, Romero D, Sanz V, López-Carrasco V Canabal J, Villasante C, Quirce S. Sputum periostin in patients with different severe asthma phenotypes. Allergy. 2015;70(5):540-6.

174. Hoshino M, Ohtawa J, Akitsu K. Association of airway wall thickness with serum periostin in steroid-naive asthma. In: Allergy Asthma Proc, vol. 37, no. 3. 2016. p. 225-30.

175. Simpson JL, Yang IA, Upham JW, Reynolds PN, Hodge S, James AL, Jenkins C, Peters MJ, Jia G, Holweg CTJ, Gibson PG. Periostin levels and eosinophilic inflammation in poorly-controlled asthma. BMC Pulm Med. 2016;16(1):67.

176. Hanania NA, Wenzel S, Rosen K, Hsieh HJ, Mosesova S, Choy DF, Lal P, Arron JR, Harris JM, Busse W. Exploring the effects of omalizumab in allergic asthma: an analysis of biomarkers in the EXTRA study. Am J Respir Crit Care Med. 2013;187(8):804-11.

177. Bjermer L, Alving K, Diamant Z, Magnussen H, Pavord I, Piacentini G, et al. Current evidence and future research needs for FeNO measurement in respiratory diseases. Respir Med. 2014;108:830-41.

178. Dweik RA, Sorkness RL, Wenzel S, Hammel J, Curran-Everett D, Comhair SA, Bleecker E, Busse W, Calhoun WJ, Castro M, Chung KF, Israel E, Jarjour N, Moore W, Peters S, Teague G, Gaston B, Erzurum SC, National Heart, Lung, and Blood Institute Severe Asthma Research Program. Use of exhaled nitric oxide measurement to identify a reactive, at-risk phenotype among patients with asthma. Am J Respir Crit Care Med. 2010;181(10):1033-41.

179. Shannon J, Ernst P, Yamauchi Y, Olivenstein R, Lemiere C, Foley S, Cicora L, Ludwig M, Hamid Q, Martin JG. Differences in airway cytokine profile in severe asthma compared to moderate asthma. Chest. 2008;133(2):420-6.

180. Gemicioglu B, Musellim B, Dogan I, Guven K. Fractional exhaled nitric oxide (FeNo) in different asthma phenotypes. Allergy Rhinol. 2014;5(3):157-61.

181. Sippel JM, Holden WE, Tilles SA, O'Hollaren M, Cook J, Thukkani N, Priest J, Nelson B, Osborne ML. Exhaled nitric oxide levels correlate with measures of disease control in asthma. J Allergy Clin Immunol. 2000;106(4):645-50

182. van Veen IH, Ten Brinke A, Sterk PJ, Sont JK, Gauw SA, Rabe KF, Bel EH. Exhaled nitric oxide predicts lung function decline in difficult-to-treat asthma. Eur Respir J. 2008;32(2):344-9.

183. Jones SL, Kittelson J, Cowan JO, Flannery EM, Hancox RJ, McLachlan CR, Taylor DR. The predictive value of exhaled nitric oxide measurements in assessing changes in asthma control. Am J Respir Crit Care Med. 2001;164(5):738-43

184. Pijnenburg MW, Hofhuis W, Hop WC, De Jongste JC. Exhaled nitric oxide predicts asthma relapse in children with clinical asthma remission. Thorax. 2005;60(3):215-8.

185. British Thoracic Society; Scottish Intercollegiate Guidelines Network (SIGN). British guideline on the management of asthma. 2016 update. http://www.sign.ac.uk/guidelines/fulltext/153/index.html. Accessed 22 Jan 2017.

186. Dweik RA, Boggs PB, Erzurum SC, Irvin CG, Leigh MW, Lundberg JO, Olin A-C, Plummer AL, Taylor DR, American Thoracic Society Committee on Interpretation of Exhaled Nitric Oxide Levels (FENO) for Clinical Applications. An official ATS clinical practice guideline: interpretation of exhaled nitric oxide levels (FENO) for clinical applications. Am J Respir Crit Care Med. 2011;184(5):602-15

187. Novartis Pharmaceuticals Canada Inc. Xolair ${ }^{\circledR}$ (omalizumab) product monograph. Date of approval: April 12, 2017.

188. Corren J, Casale TB, Lanier B, Buhl R, Holgate S, Jimenez P. Safety and tolerability of omalizumab. Clin Exp Allergy. 2009;39(6):788-97.

189. Abraham I, Alhossan A, Lee CS, Kutbi H, MacDonald K. 'Real-life' effectiveness studies of omalizumab in adult patients with severe allergic asthma: systematic review. Allergy. 2016;71(5):593-610.

190. Normansell R, Walker S, Milan SJ, Walters EH, Nair P. Omalizumab for asthma in adults and children. Cochrane Database Syst Rev. 2014;1:CD003559
191. Zazzali JL, Raimundo KP, Trzaskoma B, Rosén KE, Schatz M. Changes in asthma control, work productivity, and impairment with omalizumab: 5-year EXCELS study results. In: Allergy Asthma Proc, vol. 36, no. 4. 2015. p. 283-92.

192. Lai T, Wang S, Xu Z, Zhang C, Zhao Y, Hu Y, Cao C, Ying S, Chen Z, Li W, Wu B, Shen H. Long-term efficacy and safety of omalizumab in patients with persistent uncontrolled allergic asthma: a systematic review and meta-analysis. Sci Rep. 2015;3(5):8191.

193. Tajiri T, Matsumoto H, Gon Y, Ito R, Hashimoto S, Izuhara K, Suzukawa M, Ohta K, Ono J, Ohta S, Ito I, Oguma T, Inoue H, Iwata T, Kanemitsu Y, Nagasaki T, Niimi A, Mishima M. Utility of serum periostin and free lgE levels in evaluating responsiveness to omalizumab in patients with severe asthma. Allergy. 2016;71(10):1472-9.

194. GlaxoSmithKline Inc. Nucala ${ }^{\mathrm{TM}}$ (mepolizumab) product monograph. Date of approval: August 30, 2016.

195. Roufosse FE, Kahn JE, Gleich GJ, Schwartz LB, Singh AD, Rosenwasser LJ, Denburg JA, Ring J, Rothenberg ME, Sheikh J, Haig AE, Mallett SA, Templeton DN, Ortega HG, Klion AD. Long-term safety of mepolizumab for the treatment of hypereosinophilic syndromes. J Allergy Clin Immunol. 2013;131(2):461-7.

196. Lugogo N, Domingo C, Chanez P, Leigh R, Gilson MJ, Price RG, Yancey SW, Ortega HG. Long-term efficacy and safety of mepolizumab in patients with severe eosinophilic asthma: a multi-center, open-label. Phase IIIb study. Clin Ther. 2016;38(9):2058-70.

197. Teva Canada Limited. Cinqair ${ }^{\text {TM }}$ (reslizumab) product monograph. Date of approval: March 16, 2017.

198. Ghazi A, Trikha A, Calhoun WJ. Benralizumab-a humanized mAb to IL-5Ra with enhanced antibody-dependent cell-mediated cytotoxicity - a novel approach for the treatment of asthma. Expert Opin Biol Ther. 2012;12(1):113-8.

199. Bleecker ER, FitzGerald JM, Chanez P, Papi A, Weinstein SF, Barker P, Sproule S, Gilmartin G, Aurivillius M, Werkström V, Goldman M, SIROCCO study investigators. Efficacy and safety of benralizumab for patients with severe asthma uncontrolled with high-dosage inhaled corticosteroids and long-acting $\beta 2$-agonists (SIROCCO): a randomised, multicentre, placebo-controlled phase 3 trial. Lancet. 2016:388(10056):2115-27.

200. FitzGerald JM, Bleecker ER, Nair P, Korn S, Ohta K, Lommatzsch M, Ferguson GT, Busse WW, Barker P, Sproule S, Gilmartin G, Werkström V, Aurivillius M, Goldman M, CALIMA study investigators. Benralizumab, an anti-interleukin-5 receptor a monoclonal antibody, as add-on treatment for patients with severe, uncontrolled, eosinophilic asthma (CALIMA): a randomised, double-blind, placebo-controlled phase 3 trial. Lancet. 2016:388(10056):2128-41.

201. Vatrella A, Fabozzi I, Calabrese C, Maselli R, Pelaia G. Dupilumab: a novel treatment for asthma. J Asthma Allergy. 2014;7:123-30.

202. Wenzel S, Ford L, Pearlman D, Spector S, Sher L, Skobieranda F, Wang L, Kirkesseli S, Rocklin R, Bock B, Hamilton J, Ming JE, Radin A, Stahl N, Yancopoulos GD, Graham N, Pirozzi G. Dupilumab in persistent asthma with elevated eosinophil levels. N Engl J Med. 2013;368(26):2455-66.

203. Wenzel S, Castro M, Corren J, Maspero J, Wang L, Zhang B, Pirozzi G, Sutherland ER, Evans RR, Joish VN, Eckert L, Graham NM, Stahl N, Yancopoulos GD, Louis-Tisserand M, Teper A. Dupilumab efficacy and safety in adults with uncontrolled persistent asthma despite use of medium-to-high-dose inhaled corticosteroids plus a long-acting $\beta 2$ agonist: a randomised double-blind placebo-controlled pivotal phase 2b dose-ranging trial. Lancet. 2016;388(10039):31-44.

204. Ultsch M, Bevers J, Nakamura G, Vandlen R, Kelley RF, Wu LC, Eigenbrot C. Structural basis of signaling blockade by anti-lL-13 antibody lebrikizumab. J Mol Biol. 2013;425(8):1330-9.

205. Popovic B, Breed J, Rees DG, Gardener MJ, Vinall LM, Kemp B, Spooner J, Keen J, Minter R, Uddin F, Colice G, Wilkinson T, Vaughan T, May RD. Structural characterisation reveals mechanism of IL-13-neutralising monoclonal antibody tralokinumab as inhibition of binding to IL-13Ral and IL-13Ra2. J Mol Biol. 2017;429(2):208-19.

206. Hanania NA, Korenblat P, Chapman KR, Bateman ED, Kopecky P, Paggiaro P, Yokoyama A, Olsson J, Gray S, Holweg CT, Eisner M, Asare C, Fischer SK, Peng K, Putnam WS, Matthews JG. Efficacy and safety 
of lebrikizumab in patients with uncontrolled asthma (LAVOLTA I and LAVOLTA II): replicate, phase 3, randomised, double-blind, placebocontrolled trials. Lancet Respir Med. 2016;4(10):781-96.

207. AstraZeneca. Press release. Tralokinumab did not meet its primary endpoint of a significant reduction in the annual asthma exacerbation rate: second pivotal Phase III trial STRATOS 2 is ongoing with results expected in second half of 2017. 2017. https://www.astrazeneca.com/ media-centre/press-releases/2017/astrazeneca-provides-updateon-stratos-1-phase-iii-trial-of-tralokinumab-in-severe-uncontrolledasthma-100517.html. Accessed 15 May 2017.

\section{Submit your next manuscript to BioMed Central and we will help you at every step:}

- We accept pre-submission inquiries

- Our selector tool helps you to find the most relevant journal

- We provide round the clock customer support

- Convenient online submission

- Thorough peer review

- Inclusion in PubMed and all major indexing services

- Maximum visibility for your research

Submit your manuscript at

www.biomedcentral.com/submit 